\title{
Terminal Schwann Cell Aging: Implications for Age- Associated Neuromuscular Dysfunction
}

\author{
Sandra Fuertes-Alvarez ${ }^{1}$, Ander Izeta ${ }^{1.2 *}$ \\ ${ }^{1}$ Biodonostia, Tissue Engineering Group, Paseo Dr. Begiristain, s/n, San Sebastian 20014, Spain. \\ ${ }^{2}$ Tecnun-University of Navarra, School of Engineering, Department of Biomedical Engineering and Science, \\ Paseo Mikeletegi, 48, San Sebastian 20009, Spain.
}

[Received May 20, 2020; Revised July 1, 2020; Accepted July 8, 2020]

\begin{abstract}
Action potential is transmitted to muscle fibers through specialized synaptic interfaces called neuromuscular junctions (NMJs). These structures are capped by terminal Schwann cells (tSCs), which play essential roles during formation and maintenance of the NMJ. tSCs are implicated in the correct communication between nerves and muscles, and in reinnervation upon injury. During aging, loss of muscle mass and strength (sarcopenia and dynapenia) are due, at least in part, to the progressive loss of contacts between muscle fibers and nerves. Despite the important role of tSCs in NMJ function, very little is known on their implication in the NMJaging process and in age-associated denervation. This review summarizes the current knowledge about the implication of tSCs in the age-associated degeneration of NMJs. We also speculate on the possible mechanisms underlying the observed phenotypes.
\end{abstract}

Key words: aging, neuromuscular junction (NMJ), terminal Schwann cell (tSC), muscle denervation, sarcopenia, frailty, peripheral nervous system

\section{Introduction}

The neuromuscular junction (NMJ) is the synaptic interface through which motor neurons innervate muscle fibers $[1,2]$. Of note, not only motor nerves but also sympathetic neurons innervate skeletal muscles, and this is essential to control autonomic functions [3-6]. The correct function of the NMJ is thus essential for muscle contraction, and the impairment of synaptic activity in skeletal muscles gives rise to neuromuscular disorders such as amyotrophic lateral sclerosis (ALS) [7, 8] and myasthenia gravis [9-11]. As it happens in the rest of the organism, NMJ function may also be impaired during normal aging [12-16]. Age-associated NMJ impairment ultimately results in muscle atrophy and declined muscle mass and strength (i.e. sarcopenia and dynapenia), features that have been associated to physical frailty [1719].

The NMJ presents a characteristic pretzel-like structure [14] which is composed of five essential elements: (i) presynaptic motor nerve terminals; (ii) postsynaptic endplates in muscle fiber membranes (where acetylcholine receptors -AChRs- are anchored); (iii) basal lamina, the extracellular matrix located in the synaptic cleft [20, 21]; (iv) terminal Schwann cells (tSCs), which cover the nerve-muscle junctions (2-5 tSCs per NMJ) [22, 23], and (v) fibroblast-like cells known as kranocytes or perisynaptic fibroblasts, which cap the NMJs from above the tSCs, thus covering the end-plate area in its entirety

*Correspondence should be addressed to: Dr. Ander Izeta, Biodonostia Health Research Institute, Tissue Engineering Group, Paseo Dr. Begiristain, s/n, 20014 San Sebastian, Spain. Email: ander.izeta@biodonostia.org.

Copyright: ( $) 2020$ Fuertes-Alvarez S et al. This is an open-access article distributed under the terms of the Creative Commons Attribution License, which permits unrestricted use, distribution, and reproduction in any medium, provided the original author and source are credited. 
$[24,25]$. Of these NMJ components, kranocytes are currently the least studied. It is believed that they may play essential roles in NMJ maintenance and regeneration, since they seem to proliferate and spread upon nerve injury, before tSC sprouts develop [22, 24-26].

tSCs (also known as perisynaptic Schwann cells) represent the glial component of NMJs, capping the presynaptic nerve terminal aligned with postsynaptic AChRs. The tSCs are a subtype of non-myelinating Schwann cells (nmSCs). During embryonic development, Schwann cell precursors (SCPs) derive from the neural crest. SCPs then develop into immature Schwann cells that persist until birth. Postnatally, immature SCs differentiate into myelinating $(\mathrm{m})$ and non-myelinating (nm) Schwann cells (SCs). mSCs form myelin sheaths that wrap thicker $(\varnothing>1 \mathrm{~mm})$ axons, thus permitting an increase in their conduction speed. nmSCs do not produce myelin and are divided into two groups: Remak cells, associated to thinner $(\varnothing<1 \mathrm{~mm})$ axons, and tSCs associated to NMJs [27-29]. tSCs are essential in the synaptic function of adult NMJs as well as during formation, maintenance and remodeling of NMJs [30-34]. As it would be expected from their key structural role in the healthy NMJ, tSC dysfunction during pathological conditions may be at the origin of some neuromuscular diseases [7, 35-39].

Similarly, numerous studies have addressed NMJ degeneration during sarcopenia and aging [7, 14, 40-44]. In adults, the NMJs (one per muscle fiber) show characteristic pretzel-like structures, which are fully innervated and covered by tSCs (Fig. 1a). In contrast, aged NMJs present a number of aberrations, such as: (i) endplate fragmentation, i.e. loss of pretzel-like structure and redistribution of the $\mathrm{AChR}$ immunoreactivity into smaller "islands" (Fig. 1b-d); (ii) reduced AChR density and partial coverage of the NMJ by tSC (Fig. 1b); and (iii) partial (Fig. 1c) or even complete (Fig. 1d) denervation of the NMJ [14, 45-47].
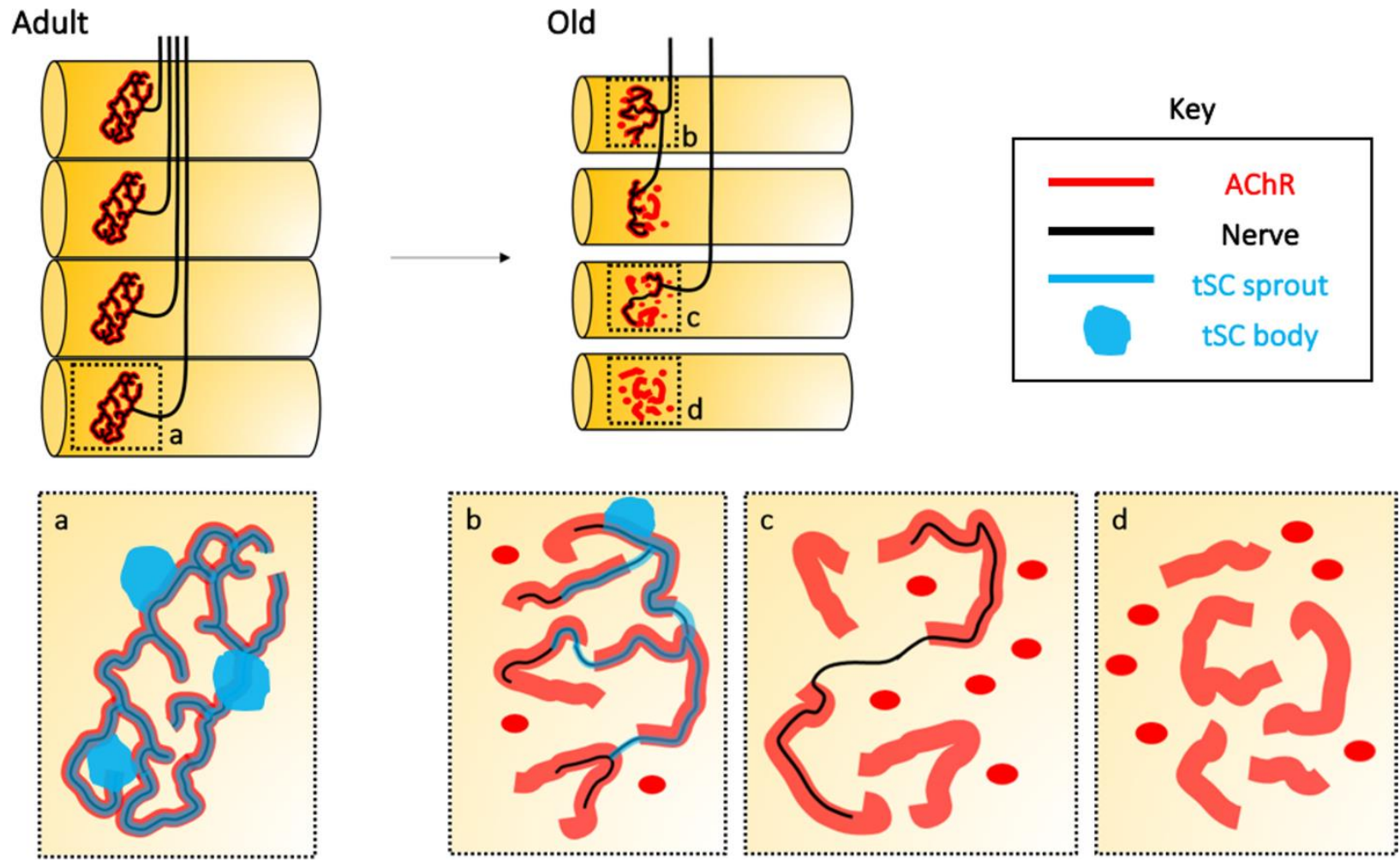

Figure 1. Age-associated changes in the neuromuscular junction (NMJ) structure. In adults, each muscle fiber is innervated by a single motor neuron-associated endplate that constitutes the NMJ. This correlation is lost upon aging, and fibers may become partially or completely denervated, and often reinnervated by bridges arising from neighboring NMJs. (a) Adult NMJs typically show a branched morphology known as "pretzel-like" structure, where acetylcholine receptor (AChR) immunoreactivity (red line) fully colocalizes with axonal branches (black line) covered by terminal Schwann cells (tSCs; blue line and blue dots). (b-d) Upon aging, pretzel-like structures are fragmented into multiple AChR-immunoreactive (red) "islands" (b). Aged NMJs become partially (c; black lines representing nerves) or completely (d) denervated. tSCs may cover aged NMJs only partially, and present aberrant processes (b; blue lines). More often, NMJs simply lose any associated tSCs (c-d). 
A fair number of recent articles has reviewed the process of age-related degeneration of NMJs from diverse points of view [14, 48-51]. However, loss of function of aged-tSCs and its implications in the NMJ aging process are less understood. This review is focused on collecting the relatively sparse evidence on age-associated tSC changes during normal aging. By extrapolating from regeneration or pathophysiological paradigms that affect the NMJs, we go on to suggest possible pathways involved in the aging of tSCs, and finally speculate on its potential link with the development of sarcopenia. Thus, this review article intends to give our personal perspective (from a "tSchwanncentric" point of view) of age-related degeneration of NMJs.

\section{Terminal Schwann cells (tSCs) in the adult NMJ}

tSCs are specialized glial cells localized over the NMJs, which regulate not only the establishment and maintenance of NMJs [34] but also the synapse efficacy between motor neuron and muscle fibers and terminal nerve guidance during NMJ-reinnervation [33, 52].

Each mature NMJ presents between 3-5 tSCs, the number correlating with the end plate size [53-55]. As aforementioned, these cells cap the synaptic zone and are essential for the maturation and long-term maintenance of NMJs [33, 56, 57]. Importantly, tSCs are able to sense and modulate synaptic activity $[58,59]$ to ensure an appropriate signal strength and an efficient transmission [33]. Targeted ablation of tSCs gives rise to nerve terminal retraction, loss of pretzel-like structure, fragmentation of the NMJ and reduced neuromuscular transmission [30, 57, 60-66].

Throughout adult life, the synaptic neuromuscular connections undergo remodeling, which seems to be more prominent in frogs than in mammals [52, 67-69]. However, the dynamic behavior of mammalian NMJs is well known $[33,67,68,70]$. Both nerves and tSCs may sprout beyond the AChR immunoreactivity limits $[67,71-$ 74], perhaps mimicking the reshaping process observed during nerve regeneration and NMJ-reinnervation. Here, tSCs form sprouts (a.k.a. "bridges" or "escaped fibers") through which tSCs and axons reach and connect with adjacent denervated endplates [54, 72, 73, 75, 76]. Overall, these results indicate that mammalian mature NMJs become plastic upon nerve injury-mediated denervation. Despite its high relevance for understanding age-associated muscular dysfunction, plasticity of the NMJ during sarcopenia and aging is still poorly understood.

tSCs are able to sense the synaptic communication and modulate synaptic properties [77-79]. Once the action potential arrives to the NMJ, vesicles loaded with acetylcholine (ACh) reach the nerve terminal membrane and release ACh into the synaptic cleft, activating the nicotinic ACh receptors (nAChRs) in the postsynaptic endplate to initiate muscle contraction. ACh molecules in the synaptic cleft are also detected by muscarinic ACh receptors (mAChR) in the tSC membrane [33, 52, 80, 81], allowing tSCs to detect the signal as well. In response to peripheral nerve stimulation, tSCs increase their levels of cytoplasmic $\mathrm{Ca}^{2+}[58,59,78,80,82-84]$. Differences in synaptic signal are detected through the expression of the $A_{2 A}$ receptors and $A_{1}$ receptors, which provide specific feedback: the sustained potentiation is mediated by $A_{2 A}$ receptors and the sustained depression is mediated by $\mathrm{A}_{1}$ receptors [85]. Moreover, tSCs differentiate synaptic activity in slow-twitch and fast-twitch muscle, and respond appropriately to each type of synapse: the tSC $\mathrm{Ca}^{2+}$ response obtained at fast-twitch synapses is larger and displays faster kinetics as compared to the response at slow twitch synapses [79].

Altogether, these studies demonstrate that tSCs sense and respond to the synaptic activity at the NMJ. Furthermore, tSCs are also capable to modulate the properties of the synaptic communication, releasing gliotransmitters (i.e. molecules with potential to modulate neuronal activity) as glutamate, prostaglandins or nitric oxide to the synaptic cleft [82, 86-94]. Hence, tSCs act not only as sensors of the neuromuscular transmission, but also as regulators of the synaptic activity.

This complex crosstalk unveils tSCs as essential elements of the NMJs, sensing and modulating synaptic signals as well as establishing "bridges" to adjacent endplates when necessary [72, 73, 75, 95]. However, changes in the tSC synaptic sensor and modulator capacity under pathological conditions have barely been addressed [8]. Similar unknowns surround tSC behavior in sarcopenia and aging [96].

\section{Terminal Schwann cells (tSCs) in the aged NMJ}

Morphological plasticity of tSCs is widely seen in neuromuscular disease and upon nerve injury (i.e. after nerve cutting, crushing, resecting, etc.) $[7,35,36,72,73$, 75, 76, 97-104]. However, little is known about the response of tSCs to an aged-NMJ environment [45, 96, 105-107]. As a consequence, the implication of tSCs in $\mathrm{NMJ}$-degeneration during aging and sarcopenia remains poorly understood.

Age-associated degeneration of NMJs has been documented both in animal models and humans, although if human NMJs degenerate upon normal aging is currently debated (see below) [14, 108-111]. During aging, the NMJ loses its characteristic "pretzel-like" structure, acquiring a more fragmented appearance $[14,45,110$, 112] (Fig. 1). Endplates acquire dotted and apparently unstructured shape, although different phenotypes are 
observed depending on the muscle studied $[16,45,112-$ 114]. The level of endplate disorganization seems to correlate with the accumulation of degeneration and regeneration cycles in muscle fibers. In healthy individuals, damaged muscle fibers are quickly replaced and reinnervated. However, the regenerated endplates show structural alterations [46]. For instance, regenerated endplates occupy larger areas than the original structure and thus present decreased density of AChR expression $[47,113]$. Moreover, during aging the number of postsynaptic folds are reduced [111], once again pointing to impairment of signaling and synaptic activity in the old individuals. Depending on the muscle analyzed, different frequencies of denervated NMJs may be observed in old individuals, both in mice [45, 112] and humans [115]. Generally, denervation compromises muscle function [116-118]. However, a decrease in muscle functionality is not seen in all muscles [16]. This variability among muscle groups remains to be explained.

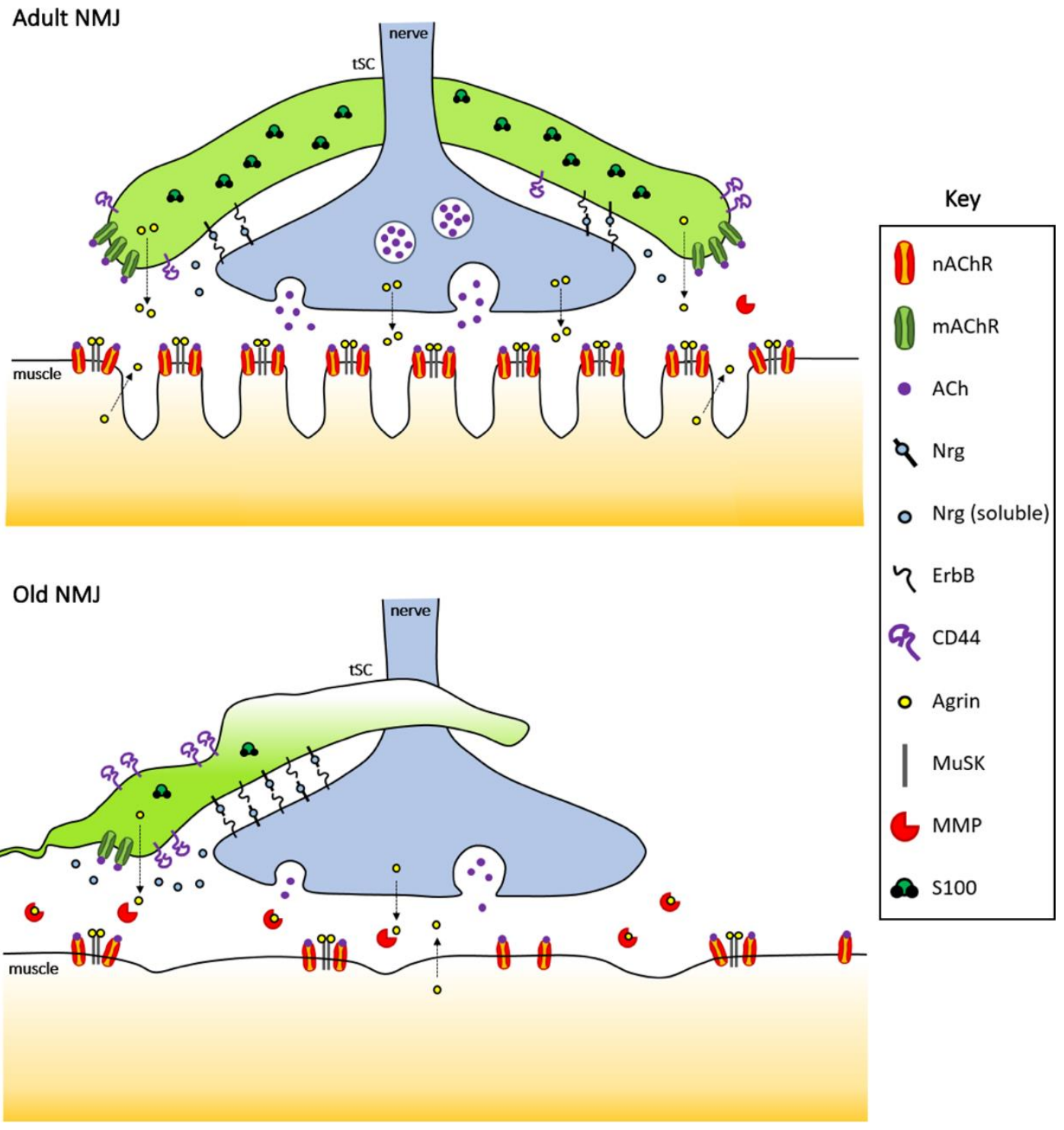

Figure 2. Age-associated disruption of signaling pathways at the NMJs. Normal adult (upper panel) and aged (lower panel) neuromuscular junctions are depicted showing major dysregulated pathways. NRG-ErbB -mediated signaling, implicated in NMJ stability and sprouting of tSCs, could also be involved in the migration of tSCs during aging that results in partial coverage of the NMJ. The cell surface glycoprotein CD44 seems to increase tSC plasticity, at least in ALS and aging mouse models. Agrin-MuSK pathway is essential for NMJ maintenance. The dysregulation of agrin levels in tSCs could induce NMJ destabilization during sarcopenia. Intracellular S100 proteins present altered expression in aged tSCs, which in turn affects $\mathrm{Ca}^{2+}$-mediated signaling. 
Another controversial point, as stated above, is whether NMJ structure degenerates in elder individuals [109-111]. Classical studies described a strong agerelated degeneration of human NMJs, as seen also in experimental animals $[110,111]$. These studies revealed a severe fragmentation of human NMJs during aging, as well as a considerable alteration of the synaptic clefts with age. Meanwhile, a more recent study by Jones et al. maintains that human NMJs remain stable during aging [109]. One interesting point revealed by this study is the fundamental differences between NMJs in humans and mice in terms of size and shape. They analyzed lower limb muscles (extensor digitorum longus, soleus, peroneus brevis and peroneus longus) after amputation. No differences in NMJ size nor fragmentation were observed during aging when all NMJs of all muscles were clustered together. However, a separate analysis of each muscle might have been more informative to account for diverse fiber-type composition in these muscles. For instance, soleus presents mainly slow-twitch fibers [119]. In mice, fast-twitch NMJs show a more aggressive degeneration than slow-twitch NMJs [112]. Another study by Boehm et al. addressed if changes in NMJ morphology arise in chachectic patients as compared with weight stable cancer patients and controls [120]. While no significant difference was found among groups, NMJs widely varied intra- and interindividually with regard nerve terminal and endplate areas. Thus, the subject of age-associated human NMJ morphological changes deserves further scrutiny. Perhaps the categorization of NMJ degeneration variables should be adjusted for changes that seem to be specific of human NMJs and which still might possibly cause partial loss of function, such as shrinking of the NMJ surface area without apparent fragmentation. Also, issues regarding muscle tissue availability for early processing after retrieval and biopsy methods should be further refined [121].

In aged NMJs, $80 \%$ of the AChR-clusters have completely lost contact with tSCs, with only $20 \%$ of the NMJs being capped by tSCs [96]. Additionally, capping surface is reduced and NMJs are partially covered in most of the cases (Fig. 1, b) [45, 106]. Moreover, aged tSCs show a completely altered structure with characteristically thin and disorganized processes [45, 107], sometimes even with aberrant presence of tSCs sprouts in the synaptic cleft [111]. Furthermore, variable S100 expression has been described [96] (Fig. 2), possibly indicating inappropriate response to calcium-mediated signals. All these anomalies observed in aged tSCs could explain, at least in part, the high percentage of denervated NMJs in aged muscles, and provide the perfect scenario to hinder the reinnervation of denervated NMJs during aging $[36,105]$. However, mechanisms involved in tSC- sprouting and their progressive degeneration during aging remain to be understood.

tSCs are extremely sensitive to the NMJ status. During nerve retraction, tSCs drastically upregulate several proteins involved in cell structure and cell junctions such as glial fibrillary acidic protein (GFAP), growth-associated protein-43 (GAP-43), low-affinity nerve growth factor (NGF) receptor p75NTR, Nestin, and cell adhesion molecule CD44 among others [22, 122]. It has been described that the number of tSC-bridges and nerve-sprouting is regulated by synaptic activity [54, 123125]: tSCs could be detecting the synaptic microenvironment of the NMJ and determining whether to form sprouts toward adjacent NMJs, strongly suggesting the existence of a link between synaptic activity and tSC-mediated repair of the NMJ. However, the protein-expression pattern of aged-tSCs and the connection with progressive impairment of the reinnervation process during aging remains unknown.

Since tSCs are essential in maintaining the structure and function of NMJs and play key roles as sensors of synaptic communication and during NMJ-reinnervation, we believe that analyzing the signaling pathways affected in age-related degeneration is of utmost importance.

\section{Intrinsic pathways altered in aged tSCs}

tSCs play key roles in the NMJ-maintenance and function, however, both conditions are altered during aging. In this section, we discuss diverse molecular pathways which could be involved in the age-related NMJ-degeneration from a "tSchwanncentric" point of view.

\subsection{Neuregulins (NRGs)}

Neuregulins (NRGs) are a family of proteins that are involved in the development and function of the mature nervous system and the impairment of NRG-signaling contributes to neurological disorders [126-128].

NRGs function as ErbB2 receptors and are implicated in Schwann cell differentiation, proliferation, migration and myelination[127-131]. It has been described that NRGs promote tSC process extension [132, 133], which is in turn required for the formation of new neuromuscular synapses and reinnervation [99]: specifically, NRG1 is essential for tSCs collateral spouting during NMJreinnervation process $[62,65,66]$.

NRGs are essential in NMJ-maintenance [66]: NRGs are expressed by motor neurons and tSCs at the NMJ (Fig. 2 ), inducing synthesis and clustering of postsynaptic nAChRs in muscle fibers [134]. Moreover, NRGs are involved in synapse elimination, plasticity of tSCs at NMJ, and migration of tSCs between endplates [132, 133, $135,136]$. Therefore, the integrity of the NMJ depends on the stability of tSCs at least in part through the regulation 
of NRG-ErbB signaling. In fact, bipartite NMJs lacking Schwann cells can be established only when muscle activity is blocked by ablation of downstream receptors, and the resulting NMJs showed increased spontaneous synaptic activity[137].

Similar tSC-plasticity and nerve-migration has been observed in ALS mouse models [36] and during aging [15]; thus, the NRG-pathway could be implicated in the denervation-reinnervation cycle in aged-NMJs through its regulatory role in tSCs. NRGs may be essential for maintaining clustered-AChRs during aging, and the correct expression of NRG in tSCs could be necessary for the regulation of cell sprouting and migration during denervation-reinnervation process in aged muscles.

NRG1 treatment has been proposed as a possible therapeutic candidate for peripheral nerve regeneration after nerve injury due to its role in myelinization [138], but it may also take part in re-stabilization of NMJs. Moreover, it has been described that NRG1-treatment in ALS mouse models enhances collateral tSC-sprouting to neighboring endplates [139].

Altogether, these data indicate that this family of proteins could act as potential regulators of tSCs morphological plasticity during aging.

\subsection{CD44}

CD44 is a cell surface glycoprotein which regulates cellcell and cell-matrix interactions in several tissues [140, 141]. It is involved in cell migration [142, 143], it is able to promote cell invasion into a hyaluronan-rich matrix [144] and promotes the formation of microtentacles to facilitate migration [145].

CD44 is strongly expressed by tSCs at the NMJs (Fig. 2 ), and it could play an essential role in the NMJ denervation-reinnervation process via tSC-morphological plasticity regulation [146]. In ALS mouse models, tSC activation and plasticity is associated with a strong increase in CD44 expression [146], which could reflect, at least in part, what happens in tSC sprouting during aging.

Moreover, it has been proposed that NRG-ErbB signaling pathway acts through interaction with CD44 [8, 147], an interesting feature since tSCs also express ErbB receptors [146, 148]. In Schwann cells of developing peripheral nerves, CD44 constitutively associates with ErbB2 and ErbB3, where it is required for receptor heterodimerization [147]. Since both CD44 and ErbB are important regulators of morphological plasticity and cell migration [142-145, 149-152], the NRG-ErbB-CD44 axis may be involved in the regulation of tSC morphological plasticity, migration and phenotypic stability during adulthood and aging.

\subsection{Agrin-MuSK}

Agrin-MuSK (Muscle-Specific Kinase) signaling pathway is essential in NMJ formation and maintenance, and is involved in synapse elimination and in the reinnervation process of NMJs [153-159].

Agrin is expressed at the NMJs by nerve terminals, muscle fibers and tSCs (Fig. 2), where it is essential for clustering of ACh-receptors in muscle fibers [155, 160164]. While the agrin isoform produced by terminal axons is more potent in promoting AChR clustering [161, 162, 164], the isoform produced by tSCs also seems to induce clustering [164]. To further complicate matters, muscle fibers also express agrin at the NMJs. However, musclederived agrin seems to be dispensable for $\mathrm{AChR}$ aggregation [162, 163, 165]. Experimental mouse models with impaired agrin expression show fragmented NMJs, mimicking aged NMJs and precocious sarcopenia [154]. Inactivation of PTEN and overexpression of EGFR downregulated agrin signaling and induced NMJ malformation as well as impaired autophagy [166]. On the other hand, Dok-7, an activator of MuSK, enhances neuromuscular transmission when overexpressed in transgenic mice, with concomitant increased penetration of tSC processes into the synaptic clefts [167]. Similarly, an increase in Agrin-MuSK pathway activity in ALS mouse models delays muscle denervation [168]. Therefore, these data suggest a link between agrin levels and NMJ fragmentation during aging and ALS [36, 154]: dysregulation of agrin levels in tSCs during aging could be implicated in the alteration of the pretzel-like structure, denervation and tSCs detachment observed in agedNMJs. Moreover, the agrin partner MuSK also decreases during sarcopenia [42], further supporting a key role of agrin-MuSK pathway during aging.

Furthermore, matrix metalloproteinases (MMPs) regulate agrin levels by degradation [159]. Several studies indicate that MMP expression increases during aging [169-171], impairing motor function [172-174]. Since tSCs express MMPs [175], aged-tSCs may regulate the concentration of agrin by increasing MMP expression levels (Fig. 2), similar to what happens in NMJ development [176]. Of note, the composition and regulation of the surrounding extracellular matrix will also have a key role in the proper functioning of the NMJ [177].

In accordance with the aforementioned data, agrinMuSK signaling axis has been proposed as a therapeutic target for myasthenia gravis and other neuromuscular disorders [178], thus reinforcing the importance of unveiling the role of agrin-MuSK pathway in tSCs during aging. 


\section{4. $\mathrm{S100}$}

The S100 protein family, belonging to a group of calciumbinding cytosolic proteins [179, 180], is involved in numerous biological processes such as cell cycle progression, cell differentiation, regulation of cell motility, migration, protein phosphorylation, inflammation, signal transduction and calcium balance [181-183], controlling the activity of its target proteins in a $\mathrm{Ca}^{2+}$-dependent manner [184]. The expression of S100 proteins has been used to characterize glial cells in the peripheral nervous system (PNS) as well as the tSC in NMJs (Fig. 2) [75, 185].

ACh in the synaptic cleft is detected by tSCs through mAChRs located in their membrane. The activation of muscarinic receptor gives rise to the activation of multiple signaling effectors which lead the regulation of intracellular $\mathrm{Ca}^{2+}$ via inositol-trisphosphate (IP3) [186, 187].

During aging, S100 expression is significantly reduced in old nmSCs versus young nmSCs [188] and fluctuating S100 expression has been observed in the few remaining aged-tSCs that cap NMJs in old mice [96] (Fig. 2). Dysregulation of $\mathrm{S} 100$ expression in tSCs could give rise to anomalies in the detection of intracellular $\mathrm{Ca}^{2+}$. Thus, aged-tSCs could somehow be "misunderstanding" the synaptic signal and modulating it in a dysfunctional manner.

\subsection{TGF- $\beta$}

TGF- $\beta$ superfamily proteins are one of the mayor extracellular regulators, and they are widely expressed in the nervous system [189]. The TGF- $\beta$ pathway plays key roles in myelinating-SCs biology [190-192] and during regeneration after nerve injury [193] but also in tSCs: it has been observed that Schwann cell-conditioned medium induces synaptogenesis in NMJs in vitro via TGF- $\beta$ [194]. It has also been suggested that tSCs release TGF- $\beta$, which in turn affects NMJ assembly and maturation in vivo [192].

TGF- $\beta$ is also a local regulator of NMJ activity [195], and suppresses the expression of the protein FGFBP1 (Fibroblast Growth Factor-Binding Protein 1) [196], which is implicated in the maintaining of NMJ structure: increasing levels of TGF- $\beta$ in the NMJ decrease FGFBP1 expression, which correlates with a degeneration of the NMJ structure [196]. Therefore, proper regulation of TGF- $\beta$ expression levels seems to be essential for NMJ stability, and the alteration of TGF- $\beta$ expression could be implicated in the NMJ disaggregation during ALS and aging. Therefore, it is essential to determine the TGF- $\beta$ expression in aged-tSCs in order to unveil, at least in part, the signaling pathways involved in NMJ-degeneration during aging.

\subsection{Growth-Associated Protein-43 (GAP-43)}

GAP-43 is a membrane-associated phosphoprotein involved in the regulation of neurite outgrowth in developing and regenerating neurons both in the PNS [197-199] and the CNS [200]. GAP-43 is also expressed by skeletal muscle fibers, where it is probably implicated in the regulation of $\mathrm{Ca}^{2+}$-homeostasis [201, 202]. More relevant for the purpose of this review, it is also expressed in both myelinating-SCs [203, 204] and non-myelinating SCs [199, 204, 205] after nerve injury. Specifically, GAP43 is expressed in tSCs at the NMJ after nerve injurymediated denervation, and its expression depends on the neural contact [76]. Functional denervation after botulinum toxin treatment increases GAP-43 expression in motor neurons but not in tSCs at the NMJs [198]. Thus, GAP-43 plays a key role in the detection of tSC-terminal nerve contact and could be acting as a sensor in the case this connection is deficient.

During aging, a reduction in GAP-43 levels in the CNS is observed [200, 206], which suggests an ageassociated loss of synaptic plasticity. However, and in spite of its essential role in the regulation of neurite outgrowth, the patterns of GAP-43 expression in the PNS and in NMJs during aging remain to be understood.

\section{Extrinsic pathways affecting aged tSCs}

Aging affect numerous pathways at the organismal level. The NMJ is obviously exposed to environmental inputs that will extrinsically induce reorganization of its structure and function, and what is known on extrinsic pathways will be reviewed in this section.

\subsection{Effect of sirtuin Sirt1 expression on tSCs structure}

Sirt1 is a protein involved in the control of biological processes such as cell survival, senescence and proliferation during aging [207-210]. It has been observed that hypothalamic Sirt1 regulates aging and longevity. Overexpression of Sirt1 extends the lifespan of mice, and specifically delays aging of skeletal muscles, maintaining a youthful appearance [211-213].

Interestingly, a recent study suggests that hypothalamic Sirt1 could be involved in the protection of the NMJs from age-related changes. Specifically, overexpression of Sirt1 in the brain of aged mice (BRASTO mice) $[214,215]$ correlates with a higher percentage of innervated NMJs, less fragmented AChR clusters and increased number of NMJs covered by tSCs. These data suggest that the sirtuin pathway could be indirectly modulating age-related NMJ degeneration through a possible protective effect on aged tSCs [96]. However, at present the evidence is correlative and causal studies are lacking. 


\subsection{Effect of inflammaging on tSCs}

Inflammaging is defined as the chronic low-grade inflammation observed in diverse organs and tissues in elderly people. It is characterized by the sustained expression of inflammatory mediator proteins, such as interleukin 6 (IL-6), interleukin 1 (IL-1), tumor necrosis factor alpha (TNF- $\alpha$ ) and C-reactive protein (CRP) [216221]; as well as by macrophage infiltration [222]. In skeletal muscle, inflammaging is associated to muscle wasting and weakness, thus accelerating a decline in muscle mass and strength, and promoting age-associated mobility disability [223-227].

How does this pro-inflammatory state affect NMJ functionality? Schwann cell senescence and limited axonal regeneration result from overexpression of IL-6 [228]. Thus, tSCs might become senescent due to inflammaging [229]. Moreover, it has been described that aged mice present poor peripheral nerve regeneration after injury compared with young animals [229-231]. However, intrinsic nerve growth capacity is not affected by aging [232]. Considering that SCs are essential in guiding nerve sprouts after nerve damage [233, 234], SC senescence could underlie, at least in part, nerve regeneration impairment in inflammaged muscles. Moreover, inflammaging could induce tSC death, thus irreversibly affecting NMJ maintenance and the formation of "bridges" to adjacent endplates. Aging also impairs the function of macrophages and other immune cells [222, 235-237]. Both macrophages and SCs are essential in clearing debris during nerve regeneration upon injury [233, 238, 239]. As a result, nerve regeneration in aged muscles may suffer from inefficient clearance of debris [229-231]. Whether the presence of macrophages or their impaired functionality affect tSC bridge formation in aged muscles remains unknown.

As aforementioned, another molecule involved in inflammaging is TNF- $\alpha$. Interestingly, overexpression of TNF- $\alpha$ in postsynaptic muscle cells depurates supernumerary NMJs by inducing the retraction of redundant nerve terminals [240]. One can posit that TNF$\alpha$ may also induce nerve terminal retraction, giving rise to partially innervated NMJs and denervated NMJs as a consequence of inflammaging. In any case, inflammaging of the local environment of the NMJ possibly induces degeneration through several of the above mechanisms in a concerted fashion. However, the present evidence is scarce and further research is needed to move from speculative ideas to certainties.

\section{6. tSC implications on the mechanisms of muscle aging and sarcopenia}

In aged individuals, muscle age-related degeneration implies the gradual loss of muscle strength (dynapenia) and muscle mass (sarcopenia), which together lead to loss of muscle function [42, 108, 117, 241-246]. The strength reduction occurs prior to significant muscle mass loss [247]. These age-associated alterations impair physical ability in older adults and are associated with progressive skeletal muscle atrophy, denervation and loss of muscle fibers (especially type II fibers or fast fibers), motor neurons loss and accumulation of fat within muscle [13, 42, 248, 249]. The age-derived degenerative processes give rise to weakness, mobility limitations, frailty and a high risk for falls $[115,250,251]$, strongly affecting the quality of life of elderly people.

Skeletal muscle fibers undergo repeated cycles of denervation-reinnervation during adult life [252] : once muscle fibers undergo denervation, they express chemotactic signals that induce reinnervation by the extension of proximal motor nerve terminals [253, 254]. These denervation-reinnervation cycles, repeated throughout adult life, lead to remodeling of the motor units [42, 255-257], disrupt the precise overlapping between the pre-synaptic nerve terminal and the postsynaptic receptors (AChRs) at the NMJs [258], and give rise to alterations in nerve terminals and in the distribution of laminin [45, 108, 157, 259]. The dynamics of denervation-reinnervation cycles begins to fail with age [257] because denervation outpaces reinnervation. As a consequence, subsets of denervated fibers are not successfully reinnervated [42, 257, 260]. Preferential denervation of the fast-twitch (type II) fibers takes place in animal models [261-264]. Loss of motoneurons has also been observed in humans [265-267]. Denervated fibers that are not successfully reinnervated undergo atrophy [42, 249, 268], thus contributing to mobility impairment and physical frailty.

Some fibers are reinnervated by axonal sprouting from slow motor neurons (that innervate slow-twitch fibers or type I fibers), which lead to remodeling of the motor units and resulting in fiber-type grouping and in a preponderance of type I motor units in aged muscles [42, $255,256,269]$, contributing to the loss of muscle strength since fast-twitch motor units determine the degree of power exerted by the underlying muscles. All these degenerative processes ultimately compromise the contractile function of the skeletal muscles during aging. The preferential denervation of type II fibers explain, at least in part, why people with a sedentary lifestyle are more susceptible to sarcopenia than people with an active lifestyle [42, 270, 271], since fast-twitch fibers are responsible for the power exerted by muscles. The disuse of type II motor units due to a limited use of explosive actions would accelerate their denervation, atrophy and degeneration.

Recently, age-associated changes of NMJs have been strongly implicated in the loss of muscle mass and 
strength during aging, since NMJ age-associated remodeling and denervation precedes muscle atrophy [12, 13, 46, 272]. On the contrary, Slater has proposed an alternative view, in which NMJ fragmentation would be the outcome of a functional regenerative process [273]. His argument is based on the lack of evidence for agerelated impairment in neuromuscular transmission, despite the NMJ undergoing morphological changes [273, 274]. To clarify matters, it would be essential to determine the origins of this controversy. Methodological aspects that differ among studies, such as different types of muscle fibers [112, 275-279], diverse localization (proximal or distal muscles) [280], or different lifelong usage of the skeletal muscles analyzed may underlie some of the observed differences. Also, how "aged" animals are defined will have an impact: a recent study found that NMJ transmission defects arose as late as 27-29 months in C57BL/6 mice [281]. The susceptibility of NMJs to suffering from denervation and the ability to be reinnervated depends largely on the morphological plasticity of tSCs. As discussed above, tSCs are essentially involved in maintaining the structure and function of NMJs in homeostatic conditions, but they also play an important role in axonal guidance and synaptic repair after denervation, even during aging $[99,105,106]$. Moreover, the impairment of tSCs gives rise to NMJfragmentation and denervation [30]. Therefore, it is plausible that aged tSCs may contribute to age-related NMJ denervation and inefficient re-innervation [13]. There have been scarce reports about age-associated tSC degeneration [45, 96, 107]: aged tSCs show disorganized appearance, altered structure that covers partially the endplate, and even absence in large part of NMJs. However, the implication of tSC aging during denervation-reinnervation cycles remains to be understood.

In addition, altered Wnt pathway might also be involved in age-associated NMJ disruption, as seen in muscle development. During development, Wnt signaling regulates NMJ formation, as it is essential for AChR clustering [14, 282-290]. Wnt ligands and Wnt-related proteins are expressed by muscle cells, nerve terminals and tSCs [260, 289-295], with possible redundant and compensatory functions at the NMJ local environment. Downregulation of Wnt upon skeletal muscle aging may signal a progressive reduction in muscle regenerative capacity [296, 297]. However, activation of Wnt in aged myogenic progenitors is also detrimental since it directs them to a fibrogenic lineage [298]. A correlation between Wnt pathway activation and fibrosis has also been observed in other aged tissues [299]. Although the regulation of Wnt signaling in aged tSCs is unknown, it seems like a worthy area of investigation.
We propose tSCs are not only a crucial element in adult NMJ maintenance and function, but also an essential player in the aged neuromuscular synapse, where agerelated degeneration of tSCs could be responsible for the denervation of muscle fibers. It is thus essential to analyze tSCs as clinical targets to avoid NMJ-denervation and/or enhance the NMJ-mediated muscle reinnervation during aging.

\section{Concluding remarks}

The increase of the life expectancy of the population in the developed world is leading to a dramatic growth of the prevalence of age-related muscle degeneration. Therefore, prevention and treatment of sarcopenia and dynapenia have emerged as fields of high medical need in order to improve the quality of life of the elderly people. Studying NMJ-associated changes during aging would let us better understand the age-related degeneration of skeletal muscles and sarcopenia. Specifically, deciphering the tSC behavior during aging would shed light on the mechanism of muscle denervation.

Morphological and physiological alterations of tSCs during aging could be implicated in the denervation process and even in the muscle remodeling observed during aging, where a preferential denervation and degeneration of type II muscle fibers takes place. The key roles of tSCs in NMJs during sarcopenia define them as perfect therapeutic targets to avoid or delay denervation derived from aging. Therapies focused on maintaining the tSCs that cap NMJs, avoiding denervation, or even improving the formation of bridges toward denervated NMJs would be of potential medical relevance.

A potentially interesting therapeutic approach is Schwann cell therapy. Schwann cell transplantation enhances myelination and spinal nerve regeneration in the spinal cord [300-304]. Schwann cell grafts could also be a potential therapy for peripheral nerve injury [305]: SC transplantation successfully enhances sciatic nerve regeneration not only in rodents [302, 306-310], but also in monkeys [311] and in humans [312]. However, SC therapy presents the obstacle of limited cell sources. Therefore, it would be interesting to explore other possibilities such as the culture of SC precursors or human induced pluripotent stem cells (iPSCs) [313-315], in order to generate healthy stem cell-derived tSCs that keep capping NMJs during aging, thus avoiding age-related denervation. Obviously, large muscle groups present an enormous logistical challenge to the application of cellbased approaches, since it is necessary to perform multiple microinjections along the muscle to facilitate transplanted cells to reach the NMJs. However, this idea might make sense on smaller muscle groups, such as those covering both urinary and anal sphincters as well as ocular 
muscles. Cell therapy is already being used to treat urinary incontinence [316], oculopharyngeal dystrophy [317] and other ocular diseases [318-320], among others. Treatment of larger muscles would possibly require cell transdifferentiation techniques mediated by small molecules or viral vectors, which are simpler to deliver [321-323]. For instance, Schwann cell precursors have been generated in vitro from fibroblasts treated with episomal vectors [324]. One could envision this type of approach promoted locally in vivo, making use of fibrotic areas abundant in aged muscle. Another interesting approach is the identification of pharmacological treatments which could avoid premature denervation or improve the reinnervation process of NMJs during aging. An interesting therapeutic candidate is Fingolimod (also known as FTY720P), a synthetic drug used in autoimmune diseases: it is approved for treatment of patients with multiple sclerosis, where it is implicated in the demyelination-remyelination process in the CNS $[325,326]$. In the PNS, Fingolimod seems to regulate myelin production and differentiation of Schwann cells [327]. Moreover, it is implicated in the reduction of neuroinflammation [328] and promotes neurite outgrowth [329]. Therefore, it would be interesting to analyze the effect of Fingolimod treatment in peripheral nerve injuries and PNS-associated diseases. Once its effect on tSCs is determined for these diseases, its viability could also be evaluated for use in age-related denervation treatment.

Recent studies highlight the complexity of age-related alterations of NMJ and the implications in sarcopenia, however the role of tSCs in this process has been largely overlooked. The idea that Schwann cell dysfunction may constitute a primary trigger of sarcopenia was originally proposed by Kwan a few years ago [330]. With this review, we hope to reignite the interest in this longstanding issue and help frame potentially interesting signaling pathways to explore. Identifying the molecular basis of tSCs dysfunction during aging is essential to understand the process of NMJ denervation and the basis of failed NMJ reinnervation. Developing new therapeutic strategies to counteract age-derived denervation might improve the quality of life of elderly people as well as improve our knowledge about healthy aging.

\section{Acknowledgements}

This work was supported by grants from Instituto de Salud Carlos III [PI16/01430 and PI19/01621], co-funded by the European Union (ERDF/ESF, "Investing in your future"); Diputación Foral de Gipuzkoa, and the Department of Economic Development and Infrastructures of the Basque Government [KK-2019/ 00006, KK-2019/00093].

\section{References}

[1] Sanes JR, Lichtman JW (1999). Development of the vertebrate neuromuscular junction. Annu Rev Neurosci, 22:389-442.

[2] Wu H, Xiong WC, Mei L (2010). To build a synapse: signaling pathways in neuromuscular junction assembly. Development, 137:1017-1033.

[3] Khan MM, Lustrino D, Silveira WA, Wild F, Straka T, Issop Y, et al. (2016). Sympathetic innervation controls homeostasis of neuromuscular junctions in health and disease. Proc Natl Acad Sci U S A, 113:746750 .

[4] Radovanovic D, Peikert K, Lindstrom M, Domellof FP (2015). Sympathetic innervation of human muscle spindles. J Anat, 226:542-548.

[5] Roatta S, Farina D (2010). Sympathetic actions on the skeletal muscle. Exerc Sport Sci Rev, 38:31-35.

[6] Straka T, Vita V, Prokshi K, Horner SJ, Khan MM, Pirazzini M, et al. (2018). Postnatal development and distribution of sympathetic innervation in mouse skeletal muscle. Int J Mol Sci, 19:1935.

[7] Cappello V, Francolini M (2017). Neuromuscular junction dismantling in amyotrophic lateral sclerosis. Int J Mol Sci, 18:2092.

[8] Moloney EB, de Winter F, Verhaagen J (2014). ALS as a distal axonopathy: molecular mechanisms affecting neuromuscular junction stability in the presymptomatic stages of the disease. Front Neurosci, 8:252.

[9] Howard JF, Jr. (2018). Myasthenia gravis: the role of complement at the neuromuscular junction. Ann N Y Acad Sci, 1412:113-128.

[10] Phillips WD, Vincent A (2016). Pathogenesis of myasthenia gravis: update on disease types, models, and mechanisms. F1000Res, 5:F1000 Faculty Rev1513.

[11] Vincent A (2002). Unravelling the pathogenesis of myasthenia gravis. Nat Rev Immunol, 2:797-804.

[12] Deschenes MR, Roby MA, Eason MK, Harris MB (2010). Remodeling of the neuromuscular junction precedes sarcopenia related alterations in myofibers. Exp Gerontol, 45:389-393.

[13] Gonzalez-Freire M, de Cabo R, Studenski SA, Ferrucci L (2014). The neuromuscular junction: aging at the crossroad between nerves and muscle. Front Aging Neurosci, 6:208.

[14] Li L, Xiong WC, Mei L (2018). Neuromuscular junction formation, aging, and disorders. Annu Rev Physiol, 80:159-188.

[15] Taetzsch T, Valdez G (2018). NMJ maintenance and repair in aging. Curr Opin Physiol, 4:57-64.

[16] Willadt S, Nash M, Slater C (2018). Age-related changes in the structure and function of mammalian neuromuscular junctions. Ann N Y Acad Sci, 1412:4153.

[17] Cesari M, Landi F, Vellas B, Bernabei R, Marzetti E (2014). Sarcopenia and physical frailty: two sides of the same coin. Front Aging Neurosci, 6:192. 
[18] Landi F, Calvani R, Cesari M, Tosato M, Martone AM, Bernabei R, et al. (2015). Sarcopenia as the biological substrate of physical frailty. Clin Geriatr Med, 31:367374.

[19] Wilkinson DJ, Piasecki M, Atherton PJ (2018). The age-related loss of skeletal muscle mass and function: Measurement and physiology of muscle fibre atrophy and muscle fibre loss in humans. Ageing Res Rev, 47:123-132.

[20] Patton BL (2003). Basal lamina and the organization of neuromuscular synapses. J Neurocytol, 32:883-903.

[21] Rogers RS, Nishimune H (2017). The role of laminins in the organization and function of neuromuscular junctions. Matrix Biol, 57-58:86-105.

[22] Sugiura Y, Lin W (2011). Neuron-glia interactions: the roles of Schwann cells in neuromuscular synapse formation and function. Biosci Rep, 31:295-302.

[23] Alvarez-Suarez P, Gawor M, Proszynski TJ (2020). Perisynaptic schwann cells - The multitasking cells at the developing neuromuscular junctions. Semin Cell Dev Biol, 104:31-38.

[24] Court FA, Gillingwater TH, Melrose S, Sherman DL, Greenshields KN, Morton AJ, et al. (2008). Identity, developmental restriction and reactivity of extralaminar cells capping mammalian neuromuscular junctions. J Cell Sci, 121:3901-3911.

[25] Weis J, Fine SM, David C, Savarirayan S, Sanes JR (1991). Integration site-dependent expression of a transgene reveals specialized features of cells associated with neuromuscular junctions. J Cell Biol, 113:1385-1397.

[26] Robertson JD (1956). The ultrastructure of a reptilian myoneural junction. J Biophys Biochem Cytol, 2:381394.

[27] Corfas G, Velardez MO, Ko CP, Ratner N, Peles E (2004). Mechanisms and roles of axon-Schwann cell interactions. J Neurosci, 24:9250-9260.

[28] Griffin JW, Thompson WJ (2008). Biology and pathology of nonmyelinating Schwann cells. Glia, 56:1518-1531.

[29] Jessen KR, Mirsky R (2005). The origin and development of glial cells in peripheral nerves. Nat Rev Neurosci, 6:671-682.

[30] Barik A, Li L, Sathyamurthy A, Xiong WC, Mei L (2016). Schwann cells in neuromuscular junction formation and maintenance. J Neurosci, 36:9770-9781.

[31] Belair EL, Vallee J, Robitaille R (2010). In vivo longterm synaptic plasticity of glial cells. J Physiol, 588:1039-1056.

[32] Castelnovo LF, Bonalume V, Melfi S, Ballabio M, Colleoni D, Magnaghi V (2017). Schwann cell development, maturation and regeneration: a focus on classic and emerging intracellular signaling pathways. Neural Regen Res, 12:1013-1023.

[33] Ko CP, Robitaille R (2015). Perisynaptic schwann cells at the neuromuscular synapse: adaptable, multitasking glial cells. Cold Spring Harb Perspect Biol, 7:a020503.

[34] Koirala S, Reddy LV, Ko CP (2003). Roles of glial cells in the formation, function, and maintenance of the neuromuscular junction. J Neurocytol, 32:9871002 .

[35] Arbour D, Tremblay E, Martineau É, Julien JP, Robitaille R (2015). Early and persistent abnormal decoding by glial cells at the neuromuscular junction in an ALS model. J Neurosci, 35:688-706.

[36] Arbour D, Vande Velde C, Robitaille R (2017). New perspectives on amyotrophic lateral sclerosis: the role of glial cells at the neuromuscular junction. J Physiol, 595:647-661.

[37] Carrasco DI, Bahr BA, Seburn KL, Pinter MJ (2016). Abnormal response of distal Schwann cells to denervation in a mouse model of motor neuron disease. Exp Neurol, 278:116-126.

[38] Carrasco DI, Seburn KL, Pinter MJ (2016). Altered terminal Schwann cell morphology precedes denervation in SOD1 mice. Exp Neurol, 275 Pt 1:172181.

[39] Snyder-Warwick AK, Satoh A, Santosa KB, Imai SI, Jablonka-Shariff A (2018). Hypothalamic Sirt1 protects terminal Schwann cells and neuromuscular junctions from age-related morphological changes. Aging Cell, 17:e12776.

[40] Alchin DR (2014). Sarcopenia: describing rather than defining a condition. J Cachexia Sarcopenia Muscle, 5:265-268.

[41] Cardoso AL, Fernandes A, Aguilar-Pimentel JA, de Angelis MH, Guedes JR, Brito MA, et al. (2018). Towards frailty biomarkers: Candidates from genes and pathways regulated in aging and age-related diseases. Ageing Res Rev, 47:214-277.

[42] Hepple RT, Rice CL (2016). Innervation and neuromuscular control in ageing skeletal muscle. $\mathrm{J}$ Physiol, 594:1965-1978.

[43] Rudolf R, Deschenes MR, Sandri M (2016). Neuromuscular junction degeneration in muscle wasting. Curr Opin Clin Nutr Metab Care, 19:177-181.

[44] Rygiel KA, Picard M, Turnbull DM (2016). The ageing neuromuscular system and sarcopenia: a mitochondrial perspective. J Physiol, 594:4499-4512. Chai RJ, Vukovic J, Dunlop S, Grounds MD, Shavlakadze T (2011). Striking denervation of neuromuscular junctions without lumbar motoneuron loss in geriatric mouse muscle. PLoS One, 6:e28090.

[46] Li Y, Lee Y, Thompson WJ (2011). Changes in aging mouse neuromuscular junctions are explained by degeneration and regeneration of muscle fiber segments at the synapse. J Neurosci, 31:14910-14919. Valdez G, Tapia JC, Kang H, Clemenson GD, Jr., Gage FH, Lichtman JW, et al. (2010). Attenuation of agerelated changes in mouse neuromuscular synapses by caloric restriction and exercise. Proc Natl Acad Sci U S A, 107:14863-14868.

[48] Badawi Y, Nishimune H (2018). Presynaptic active zones of mammalian neuromuscular junctions: Nanoarchitecture and selective impairments in aging. Neurosci Res, 127:78-88.

[49] Fish LA, Fallon JR (2020). Multiple MuSK signaling pathways and the aging neuromuscular junction. Neurosci Lett, 731:135014. 
[50] Lepore E, Casola I, Dobrowolny G, Musaro A (2019). Neuromuscular junction as an entity of nerve-muscle communication. Cells, 8:906.

[51] Liu W, Chakkalakal JV (2018). The composition, development, and regeneration of neuromuscular junctions. Curr Top Dev Biol, 126:99-124.

[52] Armati P, editor. The Biology of Schwann Cells: Development, Differentiation and Immunomodulation. Cambridge University Press; 2007.

[53] Jordan CL, Williams TJ (2001). Testosterone regulates terminal Schwann cell number and junctional size during developmental synapse elimination. Dev Neurosci, 23:441-451.

[54] Love FM, Thompson WJ (1999). Glial cells promote muscle reinnervation by responding to activitydependent postsynaptic signals. J Neurosci, 19:1039010396.

[55] Lubischer JL, Thompson WJ (1999). Neonatal partial denervation results in nodal but not terminal sprouting and a decrease in efficacy of remaining neuromuscular junctions in rat soleus muscle. J Neurosci, 19:89318944.

[56] Feng Z, Ko CP (2008). The role of glial cells in the formation and maintenance of the neuromuscular junction. Ann N Y Acad Sci, 1132:19-28.

[57] Reddy LV, Koirala S, Sugiura Y, Herrera AA, Ko CP (2003). Glial cells maintain synaptic structure and function and promote development of the neuromuscular junction in vivo. Neuron, 40:563-580.

[58] Jahromi BS, Robitaille R, Charlton MP (1992). Transmitter release increases intracellular calcium in perisynaptic Schwann cells in situ. Neuron, 8:10691077.

[59] Reist NE, Smith SJ (1992). Neurally evoked calcium transients in terminal Schwann cells at the neuromuscular junction. Proc Natl Acad Sci U S A, 89:7625-7629.

[60] Gould TW, Dominguez B, de Winter F, Yeo GW, Liu P, Sundararaman B, et al. (2019). Glial cells maintain synapses by inhibiting an activity-dependent retrograde protease signal. PLoS Genet, 15:e1007948.

[61] Halstead SK, Morrison I, O'Hanlon GM, Humphreys PD, Goodfellow JA, Plomp JJ, et al. (2005). Antidisialosyl antibodies mediate selective neuronal or Schwann cell injury at mouse neuromuscular junctions. Glia, 52:177-189.

[62] Lin W, Sanchez HB, Deerinck T, Morris JK, Ellisman M, Lee KF (2000). Aberrant development of motor axons and neuromuscular synapses in erbB2-deficient mice. Proc Natl Acad Sci U S A, 97:1299-1304.

[63] Mathey E, Armati P. 2007. Introduction to the Schwann cell. In "The Biology of Schwann Cells: Development, Differentiation and Immunomodulation", pp. 1-12.

[64] Riethmacher D, Sonnenberg-Riethmacher E, Brinkmann V, Yamaai T, Lewin GR, Birchmeier C (1997). Severe neuropathies in mice with targeted mutations in the ErbB3 receptor. Nature, 389:725-730. [65] Woldeyesus MT, Britsch S, Riethmacher D, Xu L, Sonnenberg-Riethmacher E, Abou-Rebyeh F, et al.
(1999). Peripheral nervous system defects in erbB2 mutants following genetic rescue of heart development. Genes Dev, 13:2538-2548.

[66] Wolpowitz D, Mason TB, Dietrich P, Mendelsohn M, Talmage DA, Role LW (2000). Cysteine-rich domain isoforms of the neuregulin-1 gene are required for maintenance of peripheral synapses. Neuron, 25:79-91. [67] Culican SM, Nelson CC, Lichtman JW (1998). Axon withdrawal during synapse elimination at the neuromuscular junction is accompanied by disassembly of the postsynaptic specialization and withdrawal of Schwann cell processes. J Neurosci, 18:4953-4965.

[68] Lichtman JW, Magrassi L, Purves D (1987). Visualization of neuromuscular junctions over periods of several months in living mice. J Neurosci, 7:12151222.

[69] Wernig A, Herrera AA (1986). Sprouting and remodelling at the nerve-muscle junction. Prog Neurobiol, 27:251-291.

[70] Wigston DJ (1989). Remodeling of neuromuscular junctions in adult mouse soleus. J Neurosci, 9:639-647. Robbins N, Polak J (1988). Filopodia, lamellipodia and retractions at mouse neuromuscular junctions. J Neurocytol, 17:545-561.

[72] Son YJ, Thompson WJ (1995). Nerve sprouting in muscle is induced and guided by processes extended by Schwann cells. Neuron, 14:133-141.

[73] Son YJ, Thompson WJ (1995). Schwann cell processes guide regeneration of peripheral axons. Neuron, 14:125-132.

[74] Zuo Y, Lubischer JL, Kang H, Tian L, Mikesh M, Marks A, et al. (2004). Fluorescent proteins expressed in mouse transgenic lines mark subsets of glia, neurons, macrophages, and dendritic cells for vital examination J Neurosci, 24:10999-11009.

[75] Reynolds ML, Woolf CJ (1992). Terminal Schwann cells elaborate extensive processes following denervation of the motor endplate. J Neurocytol, 21:50-66.

[76] Woolf CJ, Reynolds ML, Chong MS, Emson P, Irwin N, Benowitz LI (1992). Denervation of the motor endplate results in the rapid expression by terminal Schwann cells of the growth-associated protein GAP43. J Neurosci, 12:3999-4010.

[77] Colomar A, Robitaille R (2004). Glial modulation of synaptic transmission at the neuromuscular junction. Glia, 47:284-289.

[78] Rousse I, Robitaille R (2006). Calcium signaling in Schwann cells at synaptic and extra-synaptic sites: active glial modulation of neuronal activity. Glia, 54:691-699.

[79] Rousse I, St-Amour A, Darabid H, Robitaille R (2010). Synapse-glia interactions are governed by synaptic and intrinsic glial properties. Neuroscience, 167:621632.

[80] Rochon D, Rousse I, Robitaille R (2001). Synapse-glia interactions at the mammalian neuromuscular junction. J Neurosci, 21:3819-3829.

[81] Wright MC, Potluri S, Wang X, Dentcheva E, Gautam 
D, Tessler A, et al. (2009). Distinct muscarinic acetylcholine receptor subtypes contribute to stability and growth, but not compensatory plasticity, of neuromuscular synapses. J Neurosci, 29:14942-14955.

[82] Castonguay A, Levesque S, Robitaille R (2001). Glial cells as active partners in synaptic functions. Prog Brain Res, 132:227-240.

[83] Robitaille R (1995). Purinergic receptors and their activation by endogenous purines at perisynaptic glial cells of the frog neuromuscular junction. J Neurosci, 15:7121-7131.

[84] Robitaille R, Jahromi BS, Charlton MP (1997). Muscarinic $\mathrm{Ca} 2+$ responses resistant to muscarinic antagonists at perisynaptic Schwann cells of the frog neuromuscular junction. J Physiol, 504 ( Pt 2):337-347.

[85] Todd KJ, Darabid H, Robitaille R (2010). Perisynaptic glia discriminate patterns of motor nerve activity and influence plasticity at the neuromuscular junction. $\mathrm{J}$ Neurosci, 30:11870-11882.

[86] Araque A, Carmignoto G, Haydon PG, Oliet SH, Robitaille R, Volterra A (2014). Gliotransmitters travel in time and space. Neuron, 81:728-739.

[87] Castonguay A, Robitaille R (2001). Differential regulation of transmitter release by presynaptic and glial $\mathrm{Ca} 2+$ internal stores at the neuromuscular synapse. J Neurosci, 21:1911-1922.

[88] Descarries LM, Cai S, Robitaille R, Josephson EM, Morest DK (1998). Localization and characterization of nitric oxide synthase at the frog neuromuscular junction. J Neurocytol, 27:829-840.

[89] Lindgren CA, Newman ZL, Morford JJ, Ryan SB, Battani KA, Su Z (2013). Cyclooxygenase-2, prostaglandin E2 glycerol ester and nitric oxide are involved in muscarine-induced presynaptic enhancement at the vertebrate neuromuscular junction. J Physiol, 591:4749-4764.

[90] Pinard A, Levesque S, Vallee J, Robitaille R (2003). Glutamatergic modulation of synaptic plasticity at a PNS vertebrate cholinergic synapse. Eur J Neurosci, 18:3241-3250.

[91] Pinard A, Robitaille R (2008). Nitric oxide dependence of glutamate-mediated modulation at a vertebrate neuromuscular junction. Eur J Neurosci, 28:577-587.

[92] Robitaille R (1998). Modulation of synaptic efficacy and synaptic depression by glial cells at the frog neuromuscular junction. Neuron, 21:847-855.

[93] Todd KJ, Auld DS, Robitaille R (2007). Neurotrophins modulate neuron-glia interactions at a vertebrate synapse. Eur J Neurosci, 25:1287-1296.

[94] Todd KJ, Robitaille R (2006). Purinergic modulation of synaptic signalling at the neuromuscular junction. Pflugers Arch, 452:608-614.

[95] O'Malley JP, Waran MT, Balice-Gordon RJ (1999). In vivo observations of terminal Schwann cells at normal, denervated, and reinnervated mouse neuromuscular junctions. J Neurobiol, 38:270-286.

[96] Snyder-Warwick AK, Satoh A, Santosa KB, Imai SI, Jablonka-Shariff A (2018). Hypothalamic Sirt1 protects terminal Schwann cells and neuromuscular junctions from age-related morphological changes. Aging Cell:e12776.

[97] Jablonka-Shariff A, Lu CY, Campbell K, Monk KR, Snyder-Warwick AK (2020). Gpr126/Adgrg6 contributes to the terminal Schwann cell response at the neuromuscular junction following peripheral nerve injury. Glia, 68:1182-1200.

[98] Jonsson S, Wiberg R, McGrath AM, Novikov LN, Wiberg M, Novikova LN, et al. (2013). Effect of delayed peripheral nerve repair on nerve regeneration, Schwann cell function and target muscle recovery. PLoS One, 8:e56484.

[99] Kang H, Tian L, Mikesh M, Lichtman JW, Thompson WJ (2014). Terminal Schwann cells participate in neuromuscular synapse remodeling during reinnervation following nerve injury. J Neurosci, 34:6323-6333.

[100] Kang H, Tian L, Thompson W (2003). Terminal Schwann cells guide the reinnervation of muscle after nerve injury. J Neurocytol, 32:975-985.

[101] Kang H, Tian L, Thompson WJ (2019). Schwann cell guidance of nerve growth between synaptic sites explains changes in the pattern of muscle innervation and remodeling of synaptic sites following peripheral nerve injuries. J Comp Neurol, 527:1388-1400.

[102] Li L, Yokoyama H, Kaburagi H, Hirai T, Tsuji K, Enomoto M, et al. (2020). Remnant neuromuscular junctions in denervated muscles contribute to functional recovery in delayed peripheral nerve repair. Neural Regen Res, 15:731-738.

[103] Rich MM, Lichtman JW (1989). In vivo visualization of pre- and postsynaptic changes during synapse elimination in reinnervated mouse muscle. J Neurosci, 9:1781-1805.

[104] Santosa KB, Keane AM, Jablonka-Shariff A, Vannucci B, Snyder-Warwick AK (2018). Clinical relevance of terminal Schwann cells: An overlooked component of the neuromuscular junction. J Neurosci Res, 96:11251135 .

[105] Kawabuchi M, Tan H, Wang S (2011). Age affects reciprocal cellular interactions in neuromuscular synapses following peripheral nerve injury. Ageing Res Rev, 10:43-53.

[106] Kawabuchi M, Zhou CJ, Wang S, Nakamura K, Liu WT, Hirata K (2001). The spatiotemporal relationship among Schwann cells, axons and postsynaptic acetylcholine receptor regions during muscle reinnervation in aged rats. Anat Rec, 264:183-202.

[107] Ludatscher RM, Silbermann M, Gershon D, Reznick A (1985). Evidence of Schwann cell degeneration in the aging mouse motor end-plate region. Exp Gerontol, 20:81-91.

[108] Jang YC, Van Remmen H (2011). Age-associated alterations of the neuromuscular junction. Exp Gerontol, 46:193-198.

[109] Jones RA, Harrison C, Eaton SL, Llavero Hurtado M, Graham LC, Alkhammash L, et al. (2017). Cellular and molecular anatomy of the human neuromuscular junction. Cell Rep, 21:2348-2356.

[110] Oda K (1984). Age changes of motor innervation and 
acetylcholine receptor distribution on human skeletal muscle fibres. J Neurol Sci, 66:327-338.

[111] Wokke JH, Jennekens FG, van den Oord CJ, Veldman H, Smit LM, Leppink GJ (1990). Morphological changes in the human end plate with age. J Neurol Sci, 95:291-310.

[112] Valdez G, Tapia JC, Lichtman JW, Fox MA, Sanes JR (2012). Shared resistance to aging and ALS in neuromuscular junctions of specific muscles. PLoS One, 7:e34640.

[113] Deschenes MR, Hurst TE, Ramser AE, Sherman EG (2013). Presynaptic to postsynaptic relationships of the neuromuscular junction are held constant across age and muscle fiber type. Dev Neurobiol, 73:744-753.

[114] Sleigh JN, Burgess RW, Gillingwater TH, Cader MZ (2014). Morphological analysis of neuromuscular junction development and degeneration in rodent lumbrical muscles. J Neurosci Methods, 227:159-165.

[115] Berger MJ, Doherty TJ (2010). Sarcopenia: prevalence, mechanisms, and functional consequences. Interdiscip Top Gerontol, 37:94-114.

[116] Sayer AA, Robinson SM, Patel HP, Shavlakadze T, Cooper C, Grounds MD (2013). New horizons in the pathogenesis, diagnosis and management of sarcopenia. Age Ageing, 42:145-150.

[117] Sheth KA, Iyer CC, Wier CG, Crum AE, Bratasz A, Kolb SJ, et al. (2018). Muscle strength and size are associated with motor unit connectivity in aged mice. Neurobiol Aging, 67:128-136.

[118] Takeshita H, Yamamoto $K$, Nozato S, Inagaki $T$, Tsuchimochi H, Shirai M, et al. (2017). Modified forelimb grip strength test detects aging-associated physiological decline in skeletal muscle function in male mice. Sci Rep, 7:42323.

[119] Johnson MA, Polgar J, Weightman D, Appleton D (1973). Data on the distribution of fibre types in thirtysix human muscles. An autopsy study. J Neurol Sci, 18:111-129.

[120] Boehm I, Miller J, Wishart TM, Wigmore SJ, Skipworth RJ, Jones RA, et al. (2020). Neuromuscular junctions are stable in patients with cancer cachexia. $\mathrm{J}$ Clin Invest, 130:1461-1465.

[121] Aubertin-Leheudre M, Pion CH, Vallée J, Marchand S, Morais JA, Bélanger M, et al. (2020). Improved human muscle biopsy method to study neuromuscular junction structure and functions with aging. J Gerontol A Biol Sci Med Sci, 2019; glz292. doi:10.1093/gerona/glz292.

[122] Hyung S, Jung K, Cho SR, Jeon NL (2018). The schwann cell as an active synaptic partner. chemphyschem, 19:1123-1127.

[123] Love FM, Son YJ, Thompson WJ (2003). Activity alters muscle reinnervation and terminal sprouting by reducing the number of Schwann cell pathways that grow to link synaptic sites. J Neurobiol, 54:566-576.

[124] Tam SL, Gordon T (2003). Neuromuscular activity impairs axonal sprouting in partially denervated muscles by inhibiting bridge formation of perisynaptic Schwann cells. J Neurobiol, 57:221-234.

[125] Tam SL, Gordon T (2003). Mechanisms controlling axonal sprouting at the neuromuscular junction. J Neurocytol, 32:961-974.

[126] Esper RM, Pankonin MS, Loeb JA (2006). Neuregulins: versatile growth and differentiation factors in nervous system development and human disease. Brain Res Rev, 51:161-175.

[127] Falls DL (2003). Neuregulins: functions, forms, and signaling strategies. Exp Cell Res, 284:14-30.

[128] Falls DL (2003). Neuregulins and the neuromuscular system: 10 years of answers and questions. J Neurocytol, 32:619-647.

[129] Birchmeier C, Nave KA (2008). Neuregulin-1, a key axonal signal that drives Schwann cell growth and differentiation. Glia, 56:1491-1497.

[130] Perlin JR, Lush ME, Stephens WZ, Piotrowski T, Talbot WS (2011). Neuronal Neuregulin 1 type III directs Schwann cell migration. Development, 138:4639-4648.

[131] Salzer JL (2015). Schwann cell myelination. Cold Spring Harb Perspect Biol, 7:a020529.

[132] Hayworth CR, Moody SE, Chodosh LA, Krieg P, Rimer M, Thompson WJ (2006). Induction of neuregulin signaling in mouse schwann cells in vivo mimics responses to denervation. J Neurosci, 26:68736884.

[133] Trachtenberg JT, Thompson WJ (1997). Nerve terminal withdrawal from rat neuromuscular junctions induced by neuregulin and Schwann cells. J Neurosci, 17:6243-6255.

[134] Rimer M, Prieto AL, Weber JL, Colasante C, Ponomareva O, Fromm L, et al. (2004). Neuregulin-2 is synthesized by motor neurons and terminal Schwann cells and activates acetylcholine receptor transcription in muscle cells expressing ErbB4. Mol Cell Neurosci, 26:271-281.

[135] Lee YI, Li Y, Mikesh M, Smith I, Nave KA, Schwab MH, et al. (2016). Neuregulin1 displayed on motor axons regulates terminal Schwann cell-mediated synapse elimination at developing neuromuscular junctions. Proc Natl Acad Sci U S A, 113:E479-487.

[136] Lee YI, Thompson WJ, Harlow ML (2017). Schwann cells participate in synapse elimination at the developing neuromuscular junction. Curr Opin Neurobiol, 47:176-181.

[137] Liu Y, Sugiura Y, Chen F, Lee KF, Ye Q, Lin W (2019). Blocking skeletal muscle DHPRs/Ryr1 prevents neuromuscular synapse loss in mutant mice deficient in type III Neuregulin 1 (CRD-Nrg1). PLos Genet, 15:e1007857.

[138] Gambarotta G, Ronchi G, Geuna S, Perroteau I (2014). Neuregulin 1 isoforms could be an effective therapeutic candidate to promote peripheral nerve regeneration. Neural Regen Res, 9:1183-1185.

[139] Mancuso R, Martinez-Muriana A, Leiva T, Gregorio D, Ariza L, Morell M, et al. (2016). Neuregulin-1 promotes functional improvement by enhancing collateral sprouting in SOD1(G93A) ALS mice and after partial muscle denervation. Neurobiol Dis, 95:168-178.

[140] Borland G, Ross JA, Guy K (1998). Forms and 
functions of CD44. Immunology, 93:139-148.

[141] Goodison S, Urquidi V, Tarin D (1999). CD44 cell adhesion molecules. Mol Pathol, 52:189-196.

[142] Nam K, Oh S, Lee KM, Yoo SA, Shin I (2015). CD44 regulates cell proliferation, migration, and invasion via modulation of c-Src transcription in human breast cancer cells. Cell Signal, 27:1882-1894.

[143] Senbanjo LT, Chellaiah MA (2017). CD44: a multifunctional cell surface adhesion receptor is a regulator of progression and metastasis of cancer cells. Front Cell Dev Biol, 5:18.

[144] Tzircotis G, Thorne RF, Isacke CM (2005). Chemotaxis towards hyaluronan is dependent on CD44 expression and modulated by cell type variation in CD44-hyaluronan binding. J Cell Sci, 118:51195128.

[145] Wolf KJ, Shukla P, Springer K, Lee S, Coombes JD, Choy CJ, et al. (2020). A mode of cell adhesion and migration facilitated by CD44-dependent microtentacles. Proc Natl Acad Sci U S A, 117:1143211443.

[146] Gorlewicz A, Wlodarczyk J, Wilczek E, Gawlak M, Cabaj A, Majczynski H, et al. (2009). CD44 is expressed in non-myelinating Schwann cells of the adult rat, and may play a role in neurodegenerationinduced glial plasticity at the neuromuscular junction. Neurobiol Dis, 34:245-258.

[147] Sherman LS, Rizvi TA, Karyala S, Ratner N (2000). CD44 enhances neuregulin signaling by Schwann cells. J Cell Biol, 150:1071-1084.

[148] Trinidad JC, Fischbach GD, Cohen JB (2000). The Agrin/MuSK signaling pathway is spatially segregated from the neuregulin/ErbB receptor signaling pathway at the neuromuscular junction. J Neurosci, 20:8762-8770.

[149] Anton ES, Ghashghaei HT, Weber JL, McCann C, Fischer TM, Cheung ID, et al. (2004). Receptor tyrosine kinase ErbB4 modulates neuroblast migration and placement in the adult forebrain. Nat Neurosci, 7:1319-1328.

[150] Appert-Collin A, Hubert P, Crémel G, Bennasroune A (2015). Role of ErbB Receptors in Cancer Cell Migration and Invasion. Front Pharmacol, 6:283.

[151] Gordon-Thomson C, Jones J, Mason RS, Moore GP (2005). ErbB receptors mediate both migratory and proliferative activities in human melanocytes and melanoma cells. Melanoma Res, 15:21-28.

[152] Rio C, Rieff HI, Qi P, Khurana TS, Corfas G (1997). Neuregulin and erbB receptors play a critical role in neuronal migration. Neuron, 19:39-50.

[153] Burden SJ, Yumoto N, Zhang W (2013). The role of MuSK in synapse formation and neuromuscular disease. Cold Spring Harb Perspect Biol, 5:a009167.

[154] Butikofer L, Zurlinden A, Bolliger MF, Kunz B, Sonderegger P (2011). Destabilization of the neuromuscular junction by proteolytic cleavage of agrin results in precocious sarcopenia. Faseb J, 25:4378-4393.

[155] DeChiara TM, Bowen DC, Valenzuela DM, Simmons MV, Poueymirou WT, Thomas S, et al. (1996). The receptor tyrosine kinase MuSK is required for neuromuscular junction formation in vivo. Cell, 85:501-512.

[156] Glass DJ, Bowen DC, Stitt TN, Radziejewski C, Bruno J, Ryan TE, et al. (1996). Agrin acts via a MuSK receptor complex. Cell, 85:513-523.

[157] Samuel MA, Valdez G, Tapia JC, Lichtman JW, Sanes JR (2012). Agrin and synaptic laminin are required to maintain adult neuromuscular junctions. PLoS One, 7:e46663

[158] Zhou H, Glass DJ, Yancopoulos GD, Sanes JR (1999). Distinct domains of MuSK mediate its abilities to induce and to associate with postsynaptic specializations. J Cell Biol, 146:1133-1146.

[159] Darabid H, Perez-Gonzalez AP, Robitaille R (2014). Neuromuscular synaptogenesis: coordinating partners with multiple functions. Nat Rev Neurosci, 15:703718.

[160] Bowen DC, Sugiyama J, Ferns M, Hall ZW (1996). Neural agrin activates a high-affinity receptor in $\mathrm{C} 2$ muscle cells that is unresponsive to muscle agrin. $\mathrm{J}$ Neurosci, 16:3791-3797.

[161] Ferns MJ, Campanelli JT, Hoch W, Scheller RH, Hall Z (1993). The ability of agrin to cluster AChRs depends on alternative splicing and on cell surface proteoglycans. Neuron, 11:491-502.

[162] Gesemann M, Denzer AJ, Ruegg MA (1995). Acetylcholine receptor-aggregating activity of agrin isoforms and mapping of the active site. J Cell Biol, 128:625-636.

[163] Lin W, Burgess RW, Dominguez B, Pfaff SL, Sanes JR, Lee KF (2001). Distinct roles of nerve and muscle in postsynaptic differentiation of the neuromuscular synapse. Nature, 410:1057-1064.

[164] Yang JF, Cao G, Koirala S, Reddy LV, Ko CP (2001). Schwann cells express active agrin and enhance aggregation of acetylcholine receptors on muscle fibers. J Neurosci, 21:9572-9584.

[165] Burgess RW, Nguyen QT, Son YJ, Lichtman JW, Sanes JR (1999). Alternatively spliced isoforms of nerve- and muscle-derived agrin: their roles at the neuromuscular junction. Neuron, 23:33-44.

[166] Zhang SJ, Li XX, Yu Y, Chiu AP, Lo LH, To JC, et al. (2019). Schwann cell-specific PTEN and EGFR dysfunctions affect neuromuscular junction development by impairing Agrin signaling and autophagy. Biochem Biophys Res Commun, 515:5056.

[167] Eguchi T, Tezuka T, Fukudome T, Watanabe Y, Sagara H, Yamanashi Y (2020). Overexpression of Dok-7 in skeletal muscle enhances neuromuscular transmission with structural alterations of neuromuscular junctions: Implications in robustness of neuromuscular transmission. Biochem Biophys Res Commun, 523:214-219.

[168] Perez-Garcia MJ, Burden SJ (2012). Increasing MuSK activity delays denervation and improves motor function in ALS mice. Cell Rep, 2:497-502.

[169] Azpurua J, Eaton BA (2015). Neuronal epigenetics and the aging synapse. Front Cell Neurosci, 9:208. 
[170] Dear ML, Dani N, Parkinson W, Zhou S, Broadie K (2016). Two classes of matrix metalloproteinases reciprocally regulate synaptogenesis. Development, 143:75-87.

[171] Kaplan A, Spiller KJ, Towne C, Kanning KC, Choe GT, Geber A, et al. (2014). Neuronal matrix metalloproteinase- 9 is a determinant of selective neurodegeneration. Neuron, 81:333-348.

[172] Bonnema DD, Webb CS, Pennington WR, Stroud RE, Leonardi AE, Clark LL, et al. (2007). Effects of age on plasma matrix metalloproteinases (MMPs) and tissue inhibitor of metalloproteinases (TIMPs). J Card Fail, 13:530-540.

[173] Kim S, Ahn SH, Lee JS, Song JE, Cho SH, Jung S, et al. (2016). Differential matrix metalloprotease (MMP) expression profiles found in aged gingiva. PLoS One, 11:e0158777.

[174] Yu TY, Pang JH, Wu KP, Chen MJ, Chen CH, Tsai WC (2013). Aging is associated with increased activities of matrix metalloproteinase- 2 and -9 in tenocytes. BMC Musculoskelet Disord, 14:2.

[175] VanSaun M, Humburg BC, Arnett MG, Pence M, Werle MJ (2007). Activation of Matrix Metalloproteinase-3 is altered at the frog neuromuscular junction following changes in synaptic activity. Dev Neurobiol, 67:1488-1497.

[176] Chan ZC, Oentaryo MJ, Lee CW (2020). MMPmediated modulation of ECM environment during axonal growth and NMJ development. Neurosci Lett, 724:134822.

[177] Haronen H, Zainul Z, Naumenko N, Sormunen R, Miinalainen I, Shakirzyanova A, et al. (2019). Correct expression and localization of collagen XIII are crucial for the normal formation and function of the neuromuscular system. Eur J Neurosci, 49:1491-1511.

[178] Ohno K, Ohkawara B, Ito M (2017). Agrin-LRP4MuSK signaling as a therapeutic target for myasthenia gravis and other neuromuscular disorders. Expert Opin Ther Targets, 21:949-958.

[179] Berridge MJ, Lipp P, Bootman MD (2000). The versatility and universality of calcium signalling. Nat Rev Mol Cell Biol, 1:11-21.

[180] Heizmann CW, Fritz G, Schafer BW (2002). S100 proteins: structure, functions and pathology. Front Biosci, 7:d1356-1368.

[181] Donato R, Cannon BR, Sorci G, Riuzzi F, Hsu K, Weber DJ, et al. (2013). Functions of S100 proteins. Curr Mol Med, 13:24-57.

[182] Gross SR, Sin CG, Barraclough R, Rudland PS (2014). Joining S100 proteins and migration: for better or for worse, in sickness and in health. Cell Mol Life Sci, 71:1551-1579.

[183] Schafer BW, Heizmann CW (1996). The S100 family of EF-hand calcium-binding proteins: functions and pathology. Trends Biochem Sci, 21:134-140.

[184] Marenholz I, Heizmann CW, Fritz G (2004). S100 proteins in mouse and man: from evolution to function and pathology (including an update of the nomenclature). Biochem Biophys Res Commun, 322:1111-1122.
[185] Mirsky R, Woodhoo A, Parkinson DB, Arthur-Farraj P, Bhaskaran A, Jessen KR (2008). Novel signals controlling embryonic Schwann cell development, myelination and dedifferentiation. J Peripher Nerv Syst, 13:122-135.

[186] Espada S, Rojo AI, Salinas M, Cuadrado A (2009). The muscarinic M1 receptor activates Nrf2 through a signaling cascade that involves protein kinase $\mathrm{C}$ and inhibition of GSK-3beta: connecting neurotransmission with neuroprotection. J Neurochem, 110:1107-1119.

[187] Felder CC (1995). Muscarinic acetylcholine receptors: signal transduction through multiple effectors. Faseb J, 9:619-625.

[188] Couve E, Lovera M, Suzuki K, Schmachtenberg O (2018). Schwann cell phenotype changes in aging human dental pulp. J Dent Res, 97:347-355.

[189] McLennan IS, Koishi K (2002). The transforming growth factor-betas: multifaceted regulators of the development and maintenance of skeletal muscles, motoneurons and Schwann cells. Int J Dev Biol, 46:559-567.

[190] D'Antonio M, Droggiti A, Feltri ML, Roes J, Wrabetz L, Mirsky R, et al. (2006). TGFbeta type II receptor signaling controls Schwann cell death and proliferation in developing nerves. J Neurosci, 26:8417-8427.

[191] Einheber S, Hannocks MJ, Metz CN, Rifkin DB, Salzer JL (1995). Transforming growth factor-beta 1 regulates axon/Schwann cell interactions. J Cell Biol, 129:443-458.

[192] Fuentes-Medel Y, Ashley J, Barria R, Maloney R, Freeman M, Budnik V (2012). Integration of a retrograde signal during synapse formation by gliasecreted TGF-beta ligand. Curr Biol, 22:1831-1838.

[193] Clements MP, Byrne E, Camarillo Guerrero LF, Cattin AL, Zakka L, Ashraf A, et al. (2017). The wound microenvironment reprograms schwann cells to invasive mesenchymal-like cells to drive peripheral nerve regeneration. Neuron, 96:98-114.

[194] Feng Z, Ko CP (2008). Schwann cells promote synaptogenesis at the neuromuscular junction via transforming growth factor-beta1. J Neurosci, 28:9599-9609.

[195] Fong SW, McLennan IS, McIntyre A, Reid J, Shennan KI, Bewick GS (2010). TGF-beta2 alters the characteristics of the neuromuscular junction by regulating presynaptic quantal size. Proc Natl Acad Sci U S A, 107:13515-13519.

[196] Taetzsch T, Tenga MJ, Valdez G (2017). Muscle fibers secrete FGFBP1 to slow degeneration of neuromuscular synapses during aging and progression of ALS. J Neurosci, 37:70-82.

[197] Aigner L, Arber S, Kapfhammer JP, Laux T, Schneider C, Botteri F, et al. (1995). Overexpression of the neural growth-associated protein GAP-43 induces nerve sprouting in the adult nervous system of transgenic mice. Cell, 83:269-278.

[198] Hassan SM, Jennekens FG, Veldman H, Oestreicher BA (1994). GAP-43 and p75NGFR immunoreactivity 
in presynaptic cells following neuromuscular blockade by botulinum toxin in rat. J Neurocytol, 23:354-363.

[199] Youn SH, Maeda T, Kurisu K, Wakisaka S (1998). Growth-associated protein-43 (GAP-43) in the regenerating periodontal Ruffini endings of the rat incisor following injury to the inferior alveolar nerve. Brain Res, 787:41-48.

[200] Saland LC, Perrone-Bizzozero NI, Sower A, Samora A, Ramirez D, Apodaca A (1996). Alterations in GAP43-immunoreactive innervation in the aging rat pituitary. Neurosci Lett, 208:138-142.

[201] Caprara GA, Morabito C, Perni S, Navarra R, Guarnieri S, Mariggio MA (2016). Evidence for Altered $\mathrm{Ca}(2+)$ Handling in Growth Associated Protein 43-Knockout Skeletal Muscle. Front Physiol, 7:493.

[202] Guarnieri S, Morabito C, Paolini C, Boncompagni S, Pilla R, Fano-Illic G, et al. (2013). Growth associated protein 43 is expressed in skeletal muscle fibers and is localized in proximity of mitochondria and calcium release units. PLoS One, 8:e53267.

[203] Plantinga LC, Verhaagen J, Edwards PM, Hol EM, Bar PR, Gispen WH (1993). The expression of B-50/GAP43 in Schwann cells is upregulated in degenerating peripheral nerve stumps following nerve injury. Brain Res, 602:69-76.

[204] Curtis R, Stewart HJ, Hall SM, Wilkin GP, Mirsky R, Jessen KR (1992). GAP-43 is expressed by nonmyelin-forming Schwann cells of the peripheral nervous system. J Cell Biol, 116:1455-1464.

[205] Dubovy P, Aldskogius H (1996). Growth-associated protein (GAP-43) in terminal Schwann cells of rat Pacinian corpuscles. Neuroreport, 7:2147-2150.

[206] Casoli T, Spagna C, Fattoretti P, Gesuita R, BertoniFreddari C (1996). Neuronal plasticity in aging: a quantitative immunohistochemical study of GAP-43 distribution in discrete regions of the rat brain. Brain Res, 714:111-117.

[207] Bonkowski MS, Sinclair DA (2016). Slowing ageing by design: the rise of $\mathrm{NAD}(+)$ and sirtuin-activating compounds. Nat Rev Mol Cell Biol, 17:679-690.

[208] Carafa V, Rotili D, Forgione M, Cuomo F, Serretiello E, Hailu GS, et al. (2016). Sirtuin functions and modulation: from chemistry to the clinic. Clin Epigenetics, 8:61.

[209] Cencioni C, Spallotta F, Mai A, Martelli F, Farsetti A, Zeiher AM, et al. (2015). Sirtuin function in aging heart and vessels. J Mol Cell Cardiol, 83:55-61.

[210] Imai S, Guarente L (2014). NAD+ and sirtuins in aging and disease. Trends Cell Biol, 24:464-471.

[211] Satoh A, Imai S (2014). Hypothalamic Sirt1 in aging. Aging (Albany NY), 6:1-2.

[212] Satoh A, Imai SI, Guarente L (2017). The brain, sirtuins, and ageing. Nat Rev Neurosci, 18:362-374.

[213] Satoh A, Stein L, Imai S (2011). The role of mammalian sirtuins in the regulation of metabolism, aging, and longevity. Handb Exp Pharmacol, 206:125162.

[214] Satoh A, Brace CS, Ben-Josef G, West T, Wozniak DF, Holtzman DM, et al. (2010). SIRT1 promotes the central adaptive response to diet restriction through activation of the dorsomedial and lateral nuclei of the hypothalamus. J Neurosci, 30:10220-10232.

[215] Satoh A, Brace CS, Rensing N, Cliften P, Wozniak DF, Herzog ED, et al. (2013). Sirtl extends life span and delays aging in mice through the regulation of $\mathrm{Nk} 2$ homeobox 1 in the DMH and LH. Cell Metab, 18:416430.

[216] Ferrucci L, Corsi A, Lauretani F, Bandinelli S, Bartali B, Taub DD, et al. (2005). The origins of age-related proinflammatory state. Blood, 105:2294-2299.

[217] Ferrucci L, Fabbri E (2018). Inflammageing: chronic inflammation in ageing, cardiovascular disease, and frailty. Nat Rev Cardiol, 15:505-522.

[218] Ferrucci L, Harris TB, Guralnik JM, Tracy RP, Corti MC, Cohen HJ, et al. (1999). Serum IL-6 level and the development of disability in older persons. J Am Geriatr Soc, 47:639-646.

[219] Franceschi C, Bonafe M, Valensin S, Olivieri F, De Luca M, Ottaviani E, et al. (2000). Inflamm-aging. An evolutionary perspective on immunosenescence. Ann N Y Acad Sci, 908:244-254.

[220] Franceschi C, Capri M, Monti D, Giunta S, Olivieri F, Sevini F, et al. (2007). Inflammaging and antiinflammaging: a systemic perspective on aging and longevity emerged from studies in humans. Mech Ageing Dev, 128:92-105.

[221] Xia S, Zhang X, Zheng S, Khanabdali R, Kalionis B, $\mathrm{Wu}$ J, et al. (2016). An Update on Inflamm-Aging: Mechanisms, Prevention, and Treatment. J Immunol Res, 2016:8426874.

[222] Oishi Y, Manabe I (2016). Macrophages in age-related chronic inflammatory diseases. NPJ Aging Mech Dis, 2:16018.

[223] Degens H (2010). The role of systemic inflammation in age-related muscle weakness and wasting. Scand $\mathrm{J}$ Med Sci Sports, 20:28-38.

[224] Draganidis D, Karagounis LG, Athanailidis I, Chatzinikolaou A, Jamurtas AZ, Fatouros IG (2016). Inflammaging and Skeletal Muscle: Can Protein Intake Make a Difference? J Nutr, 146:1940-1952.

[225] Livshits G, Kalinkovich A (2019). Inflammaging as a common ground for the development and maintenance of sarcopenia, obesity, cardiomyopathy and dysbiosis. Ageing Res Rev, 56:100980.

[226] Saini A, Faulkner S, Al-Shanti N, Stewart C (2009). Powerful signals for weak muscles. Ageing Res Rev, 8:251-267.

[227] Zembron-Lacny A, Dziubek W, Wolny-Rokicka E, Dabrowska G, Wozniewski M (2019). The relation of inflammaging with skeletal muscle properties in elderly men. Am J Mens Health, 13: 1557988319841934.

[228] Saheb-Al-Zamani M, Yan Y, Farber SJ, Hunter DA, Newton P, Wood MD, et al. (2013). Limited regeneration in long acellular nerve allografts is associated with increased Schwann cell senescence. Exp Neurol, 247:165-177.

[229] Buttner R, Schulz A, Reuter M, Akula AK, Mindos T, Carlstedt A, et al. (2018). Inflammaging impairs 
peripheral nerve maintenance and regeneration. Aging cells, 17:e12833.

[230] Painter MW, Brosius Lutz A, Cheng YC, Latremoliere A, Duong K, Miller CM, et al. (2014). Diminished Schwann cell repair responses underlie age-associated impaired axonal regeneration. Neuron, 83:331-343.

[231] Scheib JL, Hoke A (2016). An attenuated immune response by Schwann cells and macrophages inhibits nerve regeneration in aged rats. Neurobiol Aging, 45:1-9.

[232] Kang H, Lichtman JW (2013). Motor axon regeneration and muscle reinnervation in young adult and aged animals. J Neurosci, 33:19480-19491.

[233] Jessen KR, Mirsky R, Lloyd AC (2015). Schwann cells: development and role in nerve repair. Cold Spring Harb Perspect Biol, 7:a020487.

[234] Nocera G, Jacob C (2020). Mechanisms of Schwann cell plasticity involved in peripheral nerve repair after injury. Cell Mol Life Sci, in press.

[235] Hearps AC, Martin GE, Angelovich TA, Cheng WJ, Maisa A, Landay AL, et al. (2012). Aging is associated with chronic innate immune activation and dysregulation of monocyte phenotype and function. Aging Cell, 11:867-875.

[236] Montgomery RR, Shaw AC (2015). Paradoxical changes in innate immunity in aging: recent progress and new directions. J Leukoc Biol, 98:937-943.

[237] Solana R, Tarazona R, Gayoso I, Lesur O, Dupuis G, Fulop T (2012). Innate immunosenescence: effect of aging on cells and receptors of the innate immune system in humans. Semin Immunol, 24:331-341.

[238] Liu P, Peng J, Han GH, Ding X, Wei S, Gao G, et al. (2019). Role of macrophages in peripheral nerve injury and repair. Neural Regen Res, 14:1335-1342.

[239] Stoll G, Griffin JW, Li CY, Trapp BD (1989). Wallerian degeneration in the peripheral nervous system: participation of both Schwann cells and macrophages in myelin degradation. J Neurocytol, 18:671-683.

[240] Fu XQ, Peng J, Wang AH, Luo ZG (2020). Tumor necrosis factor alpha mediates neuromuscular synapse elimination. Cell Discov, 6:9.

[241] Kaya RD, Nakazawa M, Hoffman RL, Clark BC (2013). Interrelationship between muscle strength, motor units, and aging. Exp Gerontol, 48:920-925.

[242] Keller K, Engelhardt M (2013). Strength and muscle mass loss with aging process. Age and strength loss. Muscles Ligaments Tendons J, 3:346-350.

[243] Mitchell WK, Williams J, Atherton P, Larvin M, Lund J, Narici M (2012). Sarcopenia, dynapenia, and the impact of advancing age on human skeletal muscle size and strength; a quantitative review. Front Physiol, 3:260.

[244] Narici MV, Maffulli N (2010). Sarcopenia: characteristics, mechanisms and functional significance. Br Med Bull, 95:139-159.

[245] Piasecki M, Ireland A, Stashuk D, Hamilton-Wright A, Jones DA, McPhee JS (2016). Age-related neuromuscular changes affecting human vastus lateralis. J Physiol, 594:4525-4536.
[246] Ward RE, Boudreau RM, Caserotti P, Harris TB, Zivkovic S, Goodpaster BH, et al. (2015). Sensory and motor peripheral nerve function and longitudinal changes in quadriceps strength. J Gerontol A Biol Sci Med Sci, 70:464-470.

[247] Goodpaster BH, Park SW, Harris TB, Kritchevsky SB, Nevitt M, Schwartz AV, et al. (2006). The loss of skeletal muscle strength, mass, and quality in older adults: the health, aging and body composition study. J Gerontol A Biol Sci Med Sci, 61:1059-1064.

[248] Liguori I, Russo G, Aran L, Bulli G, Curcio F, DellaMorte D, et al. (2018). Sarcopenia: assessment of disease burden and strategies to improve outcomes. Clin Interv Aging, 13:913-927.

[249] Rowan SL, Rygiel K, Purves-Smith FM, Solbak NM, Turnbull DM, Hepple RT (2012). Denervation causes fiber atrophy and myosin heavy chain co-expression in senescent skeletal muscle. PLoS One, 7:e29082.

[250] Clark BC, Manini TM (2010). Functional consequences of sarcopenia and dynapenia in the elderly. Curr Opin Clin Nutr Metab Care, 13:271-276.

[251] Janssen I, Shepard DS, Katzmarzyk PT, Roubenoff R (2004). The healthcare costs of sarcopenia in the United States. J Am Geriatr Soc, 52:80-85.

[252] Larsson L (1995). Motor units: remodeling in aged animals. J Gerontol A Biol Sci Med Sci, 50 Spec No:91-95.

[253] Chen ZL, Yu WM, Strickland S (2007). Peripheral regeneration. Annu Rev Neurosci, 30:209-233.

[254] Yaron A, Zheng B (2007). Navigating their way to the clinic: emerging roles for axon guidance molecules in neurological disorders and injury. Dev Neurobiol, 67:1216-1231.

[255] Kanda K, Hashizume K (1989). Changes in properties of the medial gastrocnemius motor units in aging rats. J Neurophysiol, 61:737-746.

[256] Lexell J, Downham DY (1991). The occurrence of fibre-type grouping in healthy human muscle: a quantitative study of cross-sections of whole vastus lateralis from men between 15 and 83 years. Acta Neuropathol, 81:377-381.

[257] Luff AR (1998). Age-associated changes in the innervation of muscle fibers and changes in the mechanical properties of motor units. Ann N Y Acad Sci, 854:92-101.

[258] Kulakowski SA, Parker SD, Personius KE (2011). Reduced TrkB expression results in precocious agelike changes in neuromuscular structure, neurotransmission, and muscle function. J Appl Physiol (1985), 111:844-852.

[259] Lee KM, Chand KK, Hammond LA, Lavidis NA, Noakes PG (2017). Functional decline at the aging neuromuscular junction is associated with altered laminin- $\alpha 4$ expression. Aging (Albany NY), 9:880899.

[260] Aare S, Spendiff S, Vuda M, Elkrief D, Perez A, Wu $\mathrm{Q}$, et al. (2016). Failed reinnervation in aging skeletal muscle. Skelet Muscle, 6:29.

[261] Ansved T, Larsson L (1990). Quantitative and qualitative morphological properties of the soleus 
motor nerve and the L5 ventral root in young and old rats. Relation to the number of soleus muscle fibers. J Neurol Sci, 96:269-282.

[262] Hashizume K, Kanda K, Burke RE (1988). Medial gastrocnemius motor nucleus in the rat: age-related changes in the number and size of motoneurons. J Comp Neurol, 269:425-430.

[263] Ishihara A, Araki H (1988). Effects of age on the number and histochemical properties of muscle fibers and motoneurons in the rat extensor digitorum longus muscle. Mech Ageing Dev, 45:213-221.

[264] Ishihara A, Naitoh H, Katsuta S (1987). Effects of ageing on the total number of muscle fibers and motoneurons of the tibialis anterior and soleus muscles in the rat. Brain Res, 435:355-358.

[265] Campbell EJ, Lefrak SS (1978). How aging affects the structure and function of the respiratory system. Geriatrics, 33:68-74.

[266] Doherty TJ, Brown WF (1993). The estimated numbers and relative sizes of thenar motor units as selected by multiple point stimulation in young and older adults. Muscle Nerve, 16:355-366.

[267] Tomlinson BE, Irving D (1977). The numbers of limb motor neurons in the human lumbosacral cord throughout life. J Neurol Sci, 34:213-219.

[268] Rowan SL, Purves-Smith FM, Solbak NM, Hepple RT (2011). Accumulation of severely atrophic myofibers marks the acceleration of sarcopenia in slow and fast twitch muscles. Exp Gerontol, 46:660-669.

[269] Deschenes MR (2004). Effects of aging on muscle fibre type and size. Sports Med, 34:809-824.

[270] Cartee GD, Hepple RT, Bamman MM, Zierath JR (2016). Exercise promotes healthy aging of skeletal muscle. Cell Metab, 23:1034-1047.

[271] Deschenes MR, Li S, Adan MA, Oh JJ, Ramsey HC (2018). Muscle fibers and their synapses differentially adapt to aging and endurance training. Exp Gerontol, 106:183-191.

[272] Ham D, Rüegg M. 2018. Causes and consequences of age-related changes at the neuromuscular junction. Curr Opin Physiol, 4: 32-39.

[273] Slater CR (2020). 'Fragmentation' of NMJs: a sign of degeneration or regeneration? A long journey with many junctions. Neuroscience, 439: 28-40.

[274] Willadt S, Nash M, Slater CR (2016). Age-related fragmentation of the motor endplate is not associated with impaired neuromuscular transmission in the mouse diaphragm. Sci Rep, 6:24849.

[275] Jaweed MM, Herbison GJ, Ditunno JF (1975). Denervation and reinnervation of fast and slow muscles. A histochemical study in rats. J Histochem Cytochem, 23:808-827.

[276] Lee YI (2019). Differences in the constituent fiber types contribute to the intermuscular variation in the timing of the developmental synapse elimination. Sci Rep, 9:8694.

[277] Seene T, Umnova M, Kaasik P (2017). Morphological peculiarities of neuromuscular junctions among different fiber types: Effect of exercise. Eur J Transl Myol, 27:6708.
[278] Sieck GC, Prakash YS (1997). Morphological adaptations of neuromuscular junctions depend on fiber type. Can J Appl Physiol, 22:197-230.

[279] Wang Y, Pessin JE (2013). Mechanisms for fiber-type specificity of skeletal muscle atrophy. Curr Opin Clin Nutr Metab Care, 16:243-250.

[280] Chung T, Park JS, Kim S, Montes N, Walston J, Höke A (2017). Evidence for dying-back axonal degeneration in age-associated skeletal muscle decline. Muscle Nerve, 55:894-901.

[281] Chugh D, Iyer CC, Wang X, Bobbili P, Rich MM, Arnold WD (2020). Neuromuscular junction transmission failure is a late phenotype in aging mice. Neurobiol Aging, 86:182-190.

[282] Avilés EC, Pinto C, Hanna P, Ojeda J, Pérez V, De Ferrari GV, et al. (2014). Frizzled-9 impairs acetylcholine receptor clustering in skeletal muscle cells. Front Cell Neurosci, 8:110.

[283] Barik A, Zhang B, Sohal GS, Xiong WC, Mei L (2014). Crosstalk between Agrin and Wnt signaling pathways in development of vertebrate neuromuscular junction. Dev Neurobiol, 74:828-838.

[284] Boëx M, Messéant J, Bauché S, Fontaine B, Legay C, Strochlic L (2018). Regulation of mammalian neuromuscular junction formation and maintenance by Wnt signaling. Current Opinion in Physiology, 4:8895.

[285] Koles K, Budnik V (2012). Wnt signaling in neuromuscular junction development. Cold Spring Harb Perspect Biol, 4: a008045.

[286] Korkut C, Budnik V (2009). WNTs tune up the neuromuscular junction. Nat Rev Neurosci, 10:627634.

[287] Luo ZG, Wang Q, Zhou JZ, Wang J, Luo Z, Liu M, et al. (2002). Regulation of AChR clustering by Dishevelled interacting with MuSK and PAK1. Neuron, 35:489-505.

[288] Messéant J, Ezan J, Delers P, Glebov K, Marchiol C, Lager F, et al. (2017). Wnt proteins contribute to neuromuscular junction formation through distinct signaling pathways. Development, 144:1712-1724.

[289] Shen C, Li L, Zhao K, Bai L, Wang A, Shu X, et al. (2018). Motoneuron Wnts regulate neuromuscular junction development. eLife, 7: e34625.

[290] Zhang B, Liang C, Bates R, Yin Y, Xiong WC, Mei L (2012). Wnt proteins regulate acetylcholine receptor clustering in muscle cells. Mol Brain, 5:7.

[291] Henriquez JP, Webb A, Bence M, Bildsoe H, Sahores M, Hughes SM, et al. (2008). Wnt signaling promotes AChR aggregation at the neuromuscular synapse in collaboration with agrin. Proc Natl Acad Sci U S A, 105:18812-18817.

[292] Jing L, Lefebvre JL, Gordon LR, Granato M (2009). Wnt signals organize synaptic prepattern and axon guidance through the zebrafish unplugged/MuSK receptor. Neuron, 61:721-733.

[293] Krylova O, Herreros J, Cleverley KE, Ehler E, Henriquez JP, Hughes SM, et al. (2002). WNT-3, expressed by motoneurons, regulates terminal arborization of neurotrophin-3-responsive spinal 
sensory neurons. Neuron, 35:1043-1056.

[294] Sienknecht UJ, Fekete DM (2008). Comprehensive Wnt-related gene expression during cochlear duct development in chicken. J Comp Neurol, 510:378-395.

[295] Strochlic L, Falk J, Goillot E, Sigoillot S, Bourgeois F, Delers P, et al. (2012). Wnt4 participates in the formation of vertebrate neuromuscular junction. PLoS One, 7:e29976.

[296] Conboy IM, Rando TA (2012). Heterochronic parabiosis for the study of the effects of aging on stem cells and their niches. Cell Cycle, 11:2260-2267.

[297] Hofmann JW, McBryan T, Adams PD, Sedivy JM (2014). The effects of aging on the expression of Wnt pathway genes in mouse tissues. Age, 36:9618.

[298] Brack AS, Conboy MJ, Roy S, Lee M, Kuo CJ, Keller C, et al. (2007). Increased Wnt signaling during aging alters muscle stem cell fate and increases fibrosis. Science, 317:807-810.

[299] Hu HH, Cao G, Wu XQ, Vaziri ND, Zhao YY (2020). Wnt signaling pathway in aging-related tissue fibrosis and therapies. Ageing Res Rev, 60:101063.

[300] Bachelin C, Lachapelle F, Girard C, Moissonnier P, Serguera-Lagache C, Mallet J, et al. (2005). Efficient myelin repair in the macaque spinal cord by autologous grafts of Schwann cells. Brain, 128:540549.

[301] Biernaskie J, Sparling JS, Liu J, Shannon CP, Plemel JR, Xie Y, et al. (2007). Skin-derived precursors generate myelinating Schwann cells that promote remyelination and functional recovery after contusion spinal cord injury. J Neurosci, 27:9545-9559.

[302] Hoben G, Yan Y, Iyer N, Newton P, Hunter DA, Moore AM, et al. (2015). Comparison of acellular nerve allograft modification with Schwann cells or VEGF. Hand (N Y), 10:396-402.

[303] Kanno H, Pearse DD, Ozawa H, Itoi E, Bunge MB (2015). Schwann cell transplantation for spinal cord injury repair: its significant therapeutic potential and prospectus. Rev Neurosci, 26:121-128.

[304] Kanno H, Pressman Y, Moody A, Berg R, Muir EM, Rogers JH, et al. (2014). Combination of engineered Schwann cell grafts to secrete neurotrophin and chondroitinase promotes axonal regeneration and locomotion after spinal cord injury. J Neurosci, 34:1838-1855.

[305] Han GH, Peng J, Liu P, Ding X, Wei S, Lu S, et al. (2019). Therapeutic strategies for peripheral nerve injury: decellularized nerve conduits and Schwann cell transplantation. Neural Regen Res, 14:1343-1351.

[306] Aszmann OC, Korak KJ, Luegmair M, Frey M (2008). Bridging critical nerve defects through an acellular homograft seeded with autologous schwann cells obtained from a regeneration neuroma of the proximal stump. J Reconstr Microsurg, 24:151-158.

[307] Goulart CO, Jurgensen S, Souto A, Oliveira JT, de Lima S, Tonda-Turo C, et al. (2014). A combination of Schwann-cell grafts and aerobic exercise enhances sciatic nerve regeneration. PLoS One, 9:e110090.

[308] Hess JR, Brenner MJ, Fox IK, Nichols CM, Myckatyn TM, Hunter DA, et al. (2007). Use of cold-preserved allografts seeded with autologous Schwann cells in the treatment of a long-gap peripheral nerve injury. Plast Reconstr Surg, 119:246-259.

[309] Jesuraj NJ, Santosa KB, Macewan MR, Moore AM, Kasukurthi R, Ray WZ, et al. (2014). Schwann cells seeded in acellular nerve grafts improve functional recovery. Muscle Nerve, 49:267-276.

[310] Sun XH, Che YQ, Tong XJ, Zhang LX, Feng Y, Xu $\mathrm{AH}$, et al. (2009). Improving nerve regeneration of acellular nerve allografts seeded with SCs bridging the sciatic nerve defects of rat. Cell Mol Neurobiol, 29:347-353.

[311] Levi AD, Sonntag VK, Dickman C, Mather J, Li RH, Cordoba SC, et al. (1997). The role of cultured Schwann cell grafts in the repair of gaps within the peripheral nervous system of primates. Exp Neurol, 143:25-36.

[312] Levi AD, Burks SS, Anderson KD, Dididze M, Khan A, Dietrich WD (2016). The use of autologous schwann cells to supplement sciatic nerve repair with a large gap: first in human experience. Cell Transplant, 25:1395-1403.

[313] Kim HS, Lee J, Lee DY, Kim YD, Kim JY, Lim HJ, et al. (2017). Schwann cell precursors from human pluripotent stem cells as a potential therapeutic target for myelin repair. Stem Cell Reports, 8:1714-1726.

[314] Thomson SR, Wishart TM, Patani R, Chandran S, Gillingwater TH (2012). Using induced pluripotent stem cells (iPSC) to model human neuromuscular connectivity: promise or reality? J Anat, 220:122-130.

[315] Widera D, Heimann P, Zander C, Imielski Y, Heidbreder M, Heilemann M, et al. (2011). Schwann cells can be reprogrammed to multipotency by culture. Stem Cells Dev, 20:2053-2064.

[316] Hart ML, Izeta A, Herrera-Imbroda B, Amend B, Brinchmann JE (2015). Cell therapy for stress urinary incontinence. Tissue Eng Part B Rev, 21:365-376.

[317] Périé S, Trollet C, Mouly V, Vanneaux V, Mamchaoui $\mathrm{K}$, Bouazza B, et al. (2014). Autologous myoblast transplantation for oculopharyngeal muscular dystrophy: a phase I/IIa clinical study. Mol Ther, 22:219-225

[318] Alió Del Barrio JL, Alió JL (2018). Cellular therapy of the corneal stroma: a new type of corneal surgery for keratoconus and corneal dystrophies. Eye Vis (Lond), 5:28.

[319] Sienkiewicz D, Kulak W, Okurowska-Zawada B, Paszko-Patej G, Kawnik K (2015). Duchenne muscular dystrophy: current cell therapies. Ther Adv Neurol Disord, 8:166-177.

[320] Sivan PP, Syed S, Mok P-L, Higuchi A, Murugan K, Alarfaj AA, et al. (2016). Stem cell therapy for treatment of ocular disorders. stem cells international, 2016:8304879-8304879.

[321] Fu L, Zhu X, Yi F, Liu GH, Izpisua Belmonte JC (2014). Regenerative medicine: transdifferentiation in vivo. Cell Res, 24:141-142.

[322] Merrell AJ, Stanger BZ (2016). Adult cell plasticity in vivo: de-differentiation and transdifferentiation are back in style. Nat Rev Mol Cell Biol, 17:413-425. 
[323] Pesaresi M, Sebastian-Perez R, Cosma MP (2019). Dedifferentiation, transdifferentiation and cell fusion: in vivo reprogramming strategies for regenerative medicine. Febs J, 286:1074-1093.

[324] Kim HS, Kim JY, Song CL, Jeong JE, Cho YS (2020). Directly induced human Schwann cell precursors as a valuable source of Schwann cells. Stem Cell Res Ther, 11:257.

[325] Coelho RP, Payne SG, Bittman R, Spiegel S, SatoBigbee C (2007). The immunomodulator FTY720 has a direct cytoprotective effect in oligodendrocyte progenitors. J Pharmacol Exp Ther, 323:626-635.

[326] Miron VE, Ludwin SK, Darlington PJ, Jarjour AA, Soliven B, Kennedy TE, et al. (2010). Fingolimod (FTY720) enhances remyelination following demyelination of organotypic cerebellar slices. Am J Pathol, 176:2682-2694.

[327] Kohne A, Stettner M, Jangouk P, Dehmel T, Hartung
HP, Lehmann HC, et al. (2012). Fingolimod impedes Schwann cell-mediated myelination: implications for the treatment of immune neuropathies? Arch Neurol, 69:1280-1289.

[328] Ambrosius B, Pitarokoili K, Schrewe L, Pedreiturria X, Motte J, Gold R (2017). Fingolimod attenuates experimental autoimmune neuritis and contributes to Schwann cell-mediated axonal protection. J Neuroinflammation, 14:92.

[329] Heinen A, Beyer F, Tzekova N, Hartung HP, Kury P (2015). Fingolimod induces the transition to a nerve regeneration promoting Schwann cell phenotype. Exp Neurol, 271:25-35.

[330] Kwan P (2013). Sarcopenia: the gliogenic perspective. Mech Ageing Dev, 134:349-355. 